\title{
Advancing mate choice studies in salmonids
}

\author{
Heather L. Auld (1) - David L. G. Noakes • Michael A. Banks
}

Received: 6 February 2018/ Accepted: 17 January 2019/Published online: 19 February 2019

(C) The Author(s) 2019

\begin{abstract}
Mate choice in most organisms is not random, but determined by a suite of interacting traits and environmental factors. While the selective pressures underlying differences in mate choice between species, populations, individuals and even within individuals has been gaining interest, there still remains unexplained variation in mate preferences especially in non-model systems. Despite being of social, environmental and economic importance there is comparatively little known about how salmonids and other tetraploids make mate choice decisions in the wild and the resultant reproductive success (i.e. the number of offspring which survive to sexual maturity). Resolving questions related to salmonid mate choice is of particular importance given that humans have been supplementing salmon populations through aquaculture for decades. Despite these efforts, hatchery produced fish have lower reproductive success relative to their wild counterparts and salmon populations are declining. Most studies on mate choice and
\end{abstract}

H. L. Auld ( $\square)$ · D. L. G. Noakes · M. A. Banks Department of Fisheries and Wildlife, Oregon State University, Corvallis, OR, USA

e-mail: auldh@oregonstate.edu

H. L. Auld · M. A. Banks

Coastal Oregon Marine Experiment Station, Newport, OR, USA

D. L. G. Noakes

Oregon Hatchery Research Centre, Alsea, OR, USA reproductive success in salmonids focus on body size and major histocompatibility complex based choice. However, mate choice can also be affected by other factors including other genetic factors, predation risk and social environment. Here, we (a) synthesize what is presently known about mate choice and reproductive success in salmonids, (b) identify gaps in knowledge and areas where there is a lack of consensus in results, and (c) suggest interdisciplinary ways of advancing our understanding of mate choice in salmonids and other polyploids.

Keywords Captive breeding - Mate choice . Polyploidy $\cdot$ Salmonids $\cdot$ Sexual selection

\section{Introduction}

Resolving selection pressures and mechanisms behind the skew in reproductive success (i.e. the number of offspring which survive to sexual maturity) in animal populations has long intrigued biologists. Mate choice studies have revealed a diversity of mating systems and mating preferences that are individual (e.g. Godin and Auld 2013; Edward and Chapman 2013), species and/or population dependent (Endler and Houde 1995) and affirmed that both males and females use multiple cues to assess a number of interacting factors, including chemical, morphological, and behavioural 
traits for choosing among potential mates (see Candolin 2003 for a review). Factors that affect mate choice include physical, behavioural and genetic traits, as well as environmental conditions. Examples of traits that affect mate preferences and reproductive success include body size, ornamentation, courtship displays, personality, immune system compatibility, age, condition, social environment, and sperm competition.

Despite these advancements, there is a relatively less work geared towards understanding mate choice in non-model species (e.g. animals other than Drosophila, zebra finches (Taeniopygia guttata), Trinidadian guppies, (Poecilia reticulata), zebrafish (Danio rerio)) and it is unclear how what is known about mate choice and reproductive success in model species may extend to other species, including species of social and economic importance. Current management strategies for such species often involves artificial breeding programs where humans select and breed individual mate pairs either randomly (to avoid bias), or based on morphological characteristics of choice such as increased body size (e.g. Hanson and Smith 1967; Fleming and Gross 1994) or growth rates. However, in nature mate choice is not random and the observed higher reproductive success of wild over captive origin parents in a natural context [e.g. in coho, Oncorhynchus kisutch (Whitcomb et al. 2014)] indicates that fitness (i.e. reproductive success) advantages may result from the complex natural phenomenon of mate choice among individuals themselves (Andersson and Simmons 2006).

Salmonids comprise an important group of animals that are frequently artificially bred in captivity. In many hatcheries, fish are mated and offspring released into the wild to supplement depleted wild populations or to support commercial, tribal or recreational harvest (Fleming and Petersson 2001; Katz et al. 2013) often resulting from human activities such as over-harvesting and/or habitat destruction. However, there is relatively little known about how salmonids choose mates in the wild and insufficient experimental evidence on how to maintain genetic diversity in these populations (Fraser 2008). Maintenance of genetic diversity may help populations adapt to changing environments (e.g. Reusch et al. 2005). Mismatch among human selected mating partners in fish could account for some of the observed reduced reproductive success of hatchery fish relative to wild fish (e.g. Nordeide 2006; Araki et al. 2008; Reed et al. 2015; Falica et al. 2017).

It is likely that salmonids, like other animals, use multiple behavioural and morphological cues to evaluate potential mates. However, most research on mate choice in salmonids has focused on preference for increased body size (e.g. Hanson and Smith 1967; Fleming and Gross 1994), arrival time at spawning grounds (e.g. Fleming 1996; Bentzen et al. 2001), and immune system compatibility among mates (e.g. Landry et al. 2001; Consuegra and de Leaniz 2008; Garner et al. 2010; Whitcomb et al. 2014). While research on other aspects of salmonid mate choice is increasing, there remain large gaps in our knowledge of how salmonids make mate choice decisions and how choice varies both within and between populations. Factors evident from work in other species include: courtship displays (e.g. Zuk et al. 1995), colour patterns (Hughes et al. 2013), relatedness (Pusey and Wolf 1996), and social aspects of both individual's rearing (e.g. Adkins-Regan and Krakauer 2000) and current environments, including in the context of sex ratio (e.g. Jirotkul 1999) and presence of sexual competitors (e.g. Auld and Godin 2015). A lack of focus on these important factors in salmonid mate choice and reproductive success studies could account for our limited understanding about fitness differences between wild and hatchery fish populations (e.g. Fleming and Gross 1992; Fleming et al. 1997). Moreover, because salmonids, like other important groups of fishes, are of polyploid origin (Le Comber and Smith 2004) and are still undergoing rediplodization, they have genetic inheritance patterns that differ from those of commonly studied diploids (e.g. Liu et al. 2016).

In this review, we synthesize what is known about mate choice and reproductive success in salmonids and highlight unanswered questions that can generate testable predictions to resolve uncertainties for both fisheries managers and theoretical biologists. We highlight what is already known about inter and intrasexual competition for both males and females including pre- and post-spawning processes, from both a behavioural and genetic standpoint. We also identify cross-disciplinary methodologies that could provide further insight into these processes, and propose possible avenues of research to help fill gaps in our understanding of mate choice and reproductive success in this ecologically, culturally, and economically 
important group of fish. Ultimately, we hope that this synthesis will help salmonid and other captive-context mate-choice research move forward and overall lead to improved hatchery practices.

\section{Salmonid mating system}

Salmonids are bony fish of polyploid origin that include taimen (Hucho, Parahucho), Pacific salmon and trout (Oncorhynchus), Atlantic salmon (Salmo salar) and trout (Salmo), charr (Salvelinus), longfinned charr (Salvethymus), whitefish (Coregonus and Stenodus), round whitefish (Prosopium), lenoks (Brachymystax) and graylings (Thyallmus) and the extinct Eusalmo. They are native to high latitudes of the northern hemisphere, but have been introduced around the world for commercial aquaculture or fisheries (e.g. Chile, New Zealand).

All salmonids spawn in freshwater, but breeding patterns vary across species and populations (De Gaudemar 1998). For example, some salmonids are iteroparous (reproduce multiple times) and others semelparous (breed only once). Similarly, some salmonids spend their adult life in marine environments returning to freshwater only to spawn and others spend their entire lives in freshwater. Those trout and salmon that spend their adult lives in the ocean return to their natal stream reaches to spawn (Quinn et al. 1999, 2006) (Fig. 1a). The spawn timing for salmonids is largely genetically determined and varies between species and populations within species (Bentzen et al. 2001). In most species of salmon, males arrive at the spawning grounds earlier than females (Morbey 2000), and once paired with a female, will attempt to exclude other males (Morbey 2002). Once females arrive at spawning grounds they compete with other females for access to preferred spawning habitat (Tentelier et al. 2016) and are territorial with and without the presence of males (e.g. Foote 1990).

Within large populations of salmonids inhabiting a single river system there is evidence of subpopulations inhabiting different tributaries (e.g. Verspoor 1997). For example, Ryman (1981) demonstrated population differentiation in brown trout (Salmo trutta) that were separated by less than $10 \mathrm{~km}$. Brown trout have also been found to form subpopulations within a less than a $5 \mathrm{~km}$ stretch of stream (Kazyak et al. 2016). Another study by Skaala and Nævdal (1989) found genetic differentiation among trout in different streams whose spawning areas were less than $2 \mathrm{~km}$ apart. Even low genetic differentiation can lead to differences, such as growth rate, in Atlantic Salmon (Aykanat et al. 2015). Given discrete genetic differences between populations despite spawning in relatively close proximity it is likely that individuals are reproducing with genetically similar mates.

Alternative reproductive tactics are present in salmonid mating systems with precocious males (jacks) maturing a year or more earlier than sexually
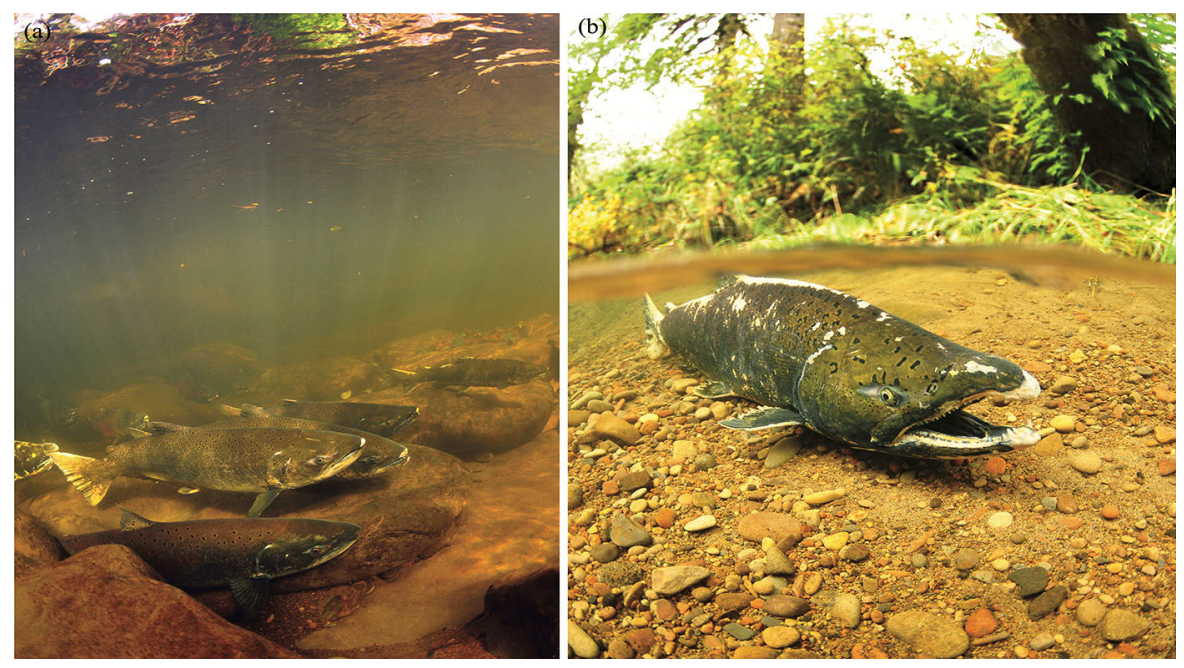

Fig. 1 a Chinook salmon (Oncorhynchus tshawytscha) on spawning grounds of Fall Creek in Oregon, b adult male Chinook salmon with developed kype and teeth 
mature adults (Gross 1984). Instead of competing with larger adult males for access to females, jacks more often assume a subordinate position in the mating hierarchy and perform sneak mating whereby they monitor the interactions between females and adult males and attempt to synchronize their sperm release with the dominant male; however, sneaking can be performed by both adults and jacks. Jacks are important in mating systems since the precocious males are unlikely to mate with their sisters who remain at sea and thus decrease the overall incidence of inbreeding (Perrier et al. 2014). Males in some species also form leks in which less attractive males (e.g. subdominant) gather around more attractive males (e.g. dominant) who are likely to attract females (Figenschou et al. 2004).

As adult males prepare to spawn and return to their natal streams they undergo development of numerous secondary sexual characteristics that can include the appearance of red coloration, thickening of skin, and enlargement of snout and teeth (Johnson et al. 2006) (Fig. 1b), which can be used to compete with rivals (Keenleyside and Dupuis 1988), and changes to fins (Thorn and Morbey 2016). Protein and stored fat are used for the development of secondary sexual characteristics, upriver migration, and egg production (Hendry and Berg 1999). Underdeveloped secondary sexual characteristics may be indicators of overall poor nutrition and foraging ability during the ocean phase of life. The development of these secondary sexual characteristics increases an individual's chance of reproductive success via intrasexual competition for access to spawning sites or mates and/or intersexual competition through attraction of potential mates (Fleming and Gross 1994). In salmonids, the effective population size is usually male biased resulting in exaggerated secondary sexual characteristics in males, competition for fertilization opportunities and differences in reproductive success between males than females (Quinn and Foote 1994).

Males and females are promiscuous (e.g. Bentzen et al. 2001) with evidence of mutual mate choice. Males can demonstrate a choice for a female by competing with other males for access to her during spawning and releasing sperm as she releases eggs for fertilization. Males also control the amount of sperm they release (Makiguchi et al. 2016a), with males releasing more sperm when spawning with larger and presumably more fecund females. When multiple females of varying quality (e.g. fecundity) are spawning, males should exhibit mate choice (Edward and Chapman 2011) as they are likely to face sperm depletion after several matings or mating attempts (Mjølnerød et al. 1998). Females can exhibit mate choice by delaying egg release until a preferred male is in position to fertilize her eggs (e.g. Berejikian et al. 2000). Males and females are likely able to synchronize gamete release using a combination of vibration and visual communication systems (e.g. Tautz and Groot 1975; Satou et al. 1994; De Gaudemar and Beall 1999).

To protect fertilized eggs from potential predators and/or from being swept downstream in a current, females will cover their eggs with gravel. Embryos develop within the gravel substrate before emerging as alevins and developing into juveniles (Groot and Margolis 1991). After hatching, there is no parental care from either parent even in iteroparous species. Hence, mate choice is likely to be strongly based on good or compatible genes that can be transmitted to offspring, rendering factors such as access to food and/ or parental care that may be important to other mating systems of no consequence to salmonids.

\section{Post-spawning sexual selection}

Even if a male is able to spawn with a female, he is not guaranteed egg fertilization or reproductive success. Two post-spawning processes affecting fertilization success are sperm competition (see Birkhead and Møller 1998) from other males and cryptic female choice (see Eberhard 1996), which will be discussed below. After ejaculation, sperm must compete with sperm from other males for fertilizations and may have differential success based on sperm characteristics, such as velocity (Gage et al. 2004; Liljedal et al. 2008; Egeland et al. 2015) (Table 1). Recent studies have also demonstrated a role of seminal fluid in the activation (Rudolfsen et al. 2015) and competitive ability of sperm (e.g. Rosengrave et al. 2009; Lewis and Pitcher 2017). For example, in the grass goby (Zosterisessor ophiocephalus) sneaker male sperm increased velocity when in contact with the seminal fluid of a territorial male (Locatello et al. 2013). Conversely, the sperm velocity of territorial males decreased in the presence of sneaker male seminal fluid (Locatello et al. 2013). The ability of males to respond to apparent risk and/or intensity of sperm 
Table 1 Traits linked to mate choice and/or offspring production in salmonids

\begin{tabular}{|c|c|c|c|c|}
\hline Trait & Sex & Preference or trait & Species & References \\
\hline \multirow[t]{6}{*}{ Body size } & 우 & Larger males & $\begin{array}{l}\text { Chinook (Oncorhynchus } \\
\text { tshawytscha) }\end{array}$ & $\begin{array}{l}\text { Berejikian et al. (2000), Neff et al. } \\
\text { (2008) }\end{array}$ \\
\hline & $\hat{0}$ & Larger females & Coho (O. kisutch) & Sargent et al. (1986) \\
\hline & 우수 & Assortative mating & $\begin{array}{l}\text { Japanese Charr } \\
\text { (Salvelinus } \\
\text { leucomaenis) }\end{array}$ & Maekawa et al. (1994) \\
\hline & +ôे & Assortative mating & $\begin{array}{l}\text { Brown trout Salmo trutta } \\
\text { L. }\end{array}$ & Serbezov et al. (2010) \\
\hline & $\hat{0}$ & $\begin{array}{l}\text { Preference for males larger than } \\
\text { themselves }\end{array}$ & & Labonne et al. (2009) \\
\hline & $\hat{\sigma}$ & Assortative mating & $\begin{array}{l}\text { Sockeye and kokanee }(O . \\
\text { nerka) }\end{array}$ & $\begin{array}{l}\text { Hanson and Smith (1967), Foote } \\
\text { (1988) }\end{array}$ \\
\hline \multirow[t]{6}{*}{ Colour } & $\hat{\sigma}$ & Red coloration & Sockeye & $\begin{array}{l}\text { Craig and Foote (2001), Foote et al. } \\
\text { (2004) }\end{array}$ \\
\hline & 우 & Brighter, blue green males & Chinook & Neff et al. (2008) \\
\hline & 우 & Assortative & & Lehnert et al. (2016a, b) \\
\hline & $\hat{\jmath}$ & Darker sired more viable offspring & Brown trout & Wedekind et al. (2008) \\
\hline & $\hat{\jmath}$ & $\begin{array}{l}\text { Fertilization potential inversely related } \\
\text { to coloration }\end{array}$ & Arctic charr (S. alpinus) & Liljedal et al. (1999) \\
\hline & 우 & $\begin{array}{l}\text { More brightly coloured females had less } \\
\text { reproductive potential }\end{array}$ & Arctic charr & Janhunen et al. (2011) \\
\hline \multirow[t]{2}{*}{ Ornamentation } & $\hat{o}$ & $\begin{array}{l}\text { More ornamented males sired higher } \\
\text { quality offspring }\end{array}$ & $\begin{array}{l}\text { Alpine whitefish } \\
\text { Coregonus sp. }\end{array}$ & Wedekind et al. (2001) \\
\hline & q & $\begin{array}{l}\text { More ornamented females had larger } \\
\text { offspring }\end{array}$ & & Kekäläinen et al. (2010) \\
\hline \multirow[t]{2}{*}{ Adipose fin } & 우 & Larger & Brown trout & Petersson et al. (1999) \\
\hline & 우 & Larger & Atlantic salmon & Järvi (1990) \\
\hline \multirow[t]{11}{*}{ MHC } & 우요 & Dissimilar & $\begin{array}{l}\text { Atlantic salmon Salmo } \\
\text { salar }\end{array}$ & $\begin{array}{l}\text { Evans et al. (2012), Landry et al. } \\
\text { (2001), Consuegra and de Leaniz } \\
\text { (2008) }\end{array}$ \\
\hline & 우 & Similar & & Yeates et al. (2009) \\
\hline & 웅 & Random & & Promerová et al. (2017) \\
\hline & 우 & Intermediate & Brown trout & Forsberg et al. (2007) \\
\hline & 우 & Dissimilar & Chinook & $\begin{array}{l}\text { Neff et al. (2008), Garner et al. } \\
\text { (2010) }\end{array}$ \\
\hline & $\hat{0}$ & Random & & Neff et al. (2008) \\
\hline & $\hat{\jmath}$ & $\begin{array}{l}\text { } \text { with whom they would produce } \\
\text { offspring with intermediate diversity at } \\
\text { MHC II }\end{array}$ & & Evans et al. (2013) \\
\hline & 웅 & $\begin{array}{l}\text { More similar at MHC I-A1and random } \\
\text { at MHC II-B1 }\end{array}$ & & Lehnert et al. (2017) \\
\hline & $\hat{o}$ & $\begin{array}{l}\text { Great fertilization success if } \\
\text { heterozygous }\end{array}$ & Arctic charr & Skarstein et al. (2005) \\
\hline & q & $\begin{array}{l}\text { Greater fertilization for similar sneaker } \\
\text { males }\end{array}$ & Atlantic salmon & Weir et al. (2012) \\
\hline & 웅 & Variable across years & Coho & Whitcomb et al. (2014) \\
\hline \multirow[t]{2}{*}{ Density } & OSR & No evidence & Chinook & Neff et al. (2008) \\
\hline & & $\begin{array}{l}\text { Density of males affected offspring } \\
\text { production }\end{array}$ & Atlantic salmon & Weir et al. (2012) \\
\hline
\end{tabular}


Table 1 continued

\begin{tabular}{|c|c|c|c|c|}
\hline Trait & Sex & Preference or trait & Species & References \\
\hline Dominance & 우 & $\begin{array}{l}\text { Preference for dominant mate } \\
\text { Increased fertilization success }\end{array}$ & $\begin{array}{l}\text { Arctic charr } \\
\text { Coho salmon }\end{array}$ & $\begin{array}{l}\text { Sørum et al. (2011) } \\
\text { Berejikian et al. (2001) }\end{array}$ \\
\hline Kinship & 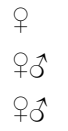 & $\begin{array}{l}\text { Dissimilar } \\
\text { Random } \\
\text { Variable }\end{array}$ & Atlantic salmon & $\begin{array}{l}\text { Garant et al. (2005) } \\
\text { Landry et al. (2001) } \\
\text { Houde et al. (2011) }\end{array}$ \\
\hline Life History & 웅 & $\begin{array}{l}\text { Assortative mating } \\
\text { No assortative mating }\end{array}$ & $\begin{array}{l}\text { Sockeye and kokanee } \\
\text { Brook charr ( } S \text {. } \\
\text { fontinalis) }\end{array}$ & $\begin{array}{l}\text { Foote and Larkin (1988), Thériault } \\
\text { et al. (2007) }\end{array}$ \\
\hline Origin & 㝏 & $\begin{array}{l}\text { Context-dependent preference for males } \\
\text { from the same population }\end{array}$ & Brown trout & Bolgan et al. (2017) \\
\hline Ovulation & $\hat{0}$ & Courtship towards + who had ovulated & $\begin{array}{l}\text { Masu salmon } O \text {. masu } \\
\text { and Biwa trout }(O . \\
\text { rhodurus })\end{array}$ & Honda (1982) \\
\hline Courtship & q & More intense $\widehat{\delta}$ courtship & Atlantic salmon & De Gaudemar et al. (2000) \\
\hline $\begin{array}{l}\text { Immediate } \\
\text { social } \\
\text { environment }\end{array}$ & & No known studies & & \\
\hline Parasite load & & No known studies & & \\
\hline Predation risk & & No known studies & & \\
\hline Cognition & & No known studies & & \\
\hline Familiarity & & No known studies & & \\
\hline Gene Drive & & No known studies & & \\
\hline Personality & & No known studies & & \\
\hline Ploidy & & No known studies & & \\
\hline
\end{tabular}

competition (e.g. through release of more sperm) should increase their reproductive success (Bretman et al. 2009).

Sperm competition can play a role in the reproductive success of salmonids. Salmon sperm (milt), which is immobile until it is activated by water, is viable for approximately $30 \mathrm{~s}$ and female eggs can be fertilized for approximately $40 \mathrm{~s}$ after which the micropyle closes and no sperm are able to enter (Hoysak and Liley 2001); however, in sockeye salmon (Oncorhynchus nerka) a contact time of 5-10 s for egg and sperm is sufficient to ensure high levels of fertilization (Hoysak and Liley 2001). For a given male to be able to successfully fertilize eggs he needs to appropriately time sperm release and would benefit from having fast sperm that can reach eggs before other sperm fertilize the eggs. Pitcher et al. (2009) found adult male coho salmon with less red reflectance and high UV reflection in their body coloration had higher sperm velocity compared to males with more red coloration suggesting a tradeoff between attractive coloration leading to a better position in the dominance hierarchy and sperm quality. They found no relationship between body size and sperm velocity, longevity, or any morphological sperm trait. Similarly, in Alpine whitefish (Coregonus zugensis), older males on average maintain a higher position in the dominance hierarchy, but also had slower sperm relative to younger males (Rudolfsen et al. 2008). Moreover, males with less ornamentation had higher sperm motility and greater fertilization success, but produced less viable embryos (Kekäläinen et al. 2015). Differences in competitive ability of sperm may in part explain differences in reproductive success between hatchery and wild males; however, Camarillo-Sepulveda et al. (2015) found most sperm characteristics of 
wild and farmed Atlantic salmon similar with the exception of wild salmon sperm having a longer flagellum, but this did not translate into increased fertilization rates. Their study had a relatively low sample size of 10 wild males, 21 farmed males, and 8 females each of wild and farmed origin. Lumley et al. (2016) also showed no benefit to Atlantic salmon offspring when there was opportunity for sperm competition and cryptic female choice; however, they only looked at offspring growth and survival for 140 days and so there is no measure of lifetime reproductive success. Any increase in offspring growth and survival may be apparent later in life. There are apparently no studies that compare fertilization rates between wild and hatchery males in other salmonids.

Males who are able to circumvent premating female choice and/or males who produce sperm that reach eggs before rival sperm may still be excluded from fertilizations by cryptic female choice (e.g. Rosengrave et al. 2008, 2016; Lehnert et al. 2016a, 2017). Cryptic female choice occurs when a female or an extension of the female (i.e. eggs or ovarian fluid) favors certain sperm over others. For internal fertilizers, this occurs within the reproductive tract of the female. It was initially thought that cryptic female choice was limited to internal fertilizers, but recent studies demonstrate the ability of cryptic female choice, mediated by ovarian fluid, to occur in external fertilizers such as Chinook salmon (Oncorhynchus tshawytscha) (Rosengrave et al. 2008, 2016; Lehnert et al. 2016a, 2017; but see Wedekind et al. 2004; Lumley et al. 2016), and trout (e.g. Galvano et al. 2013; Yeates et al. 2013). Also, Arctic charr (Salvelinus alpinus) sperm from dominant males had greater motility in ovarian fluid (Egeland et al. 2016). This increased mobility could be cryptic female choice, via ovarian fluid, for dominant male sperm or dominant male sperm could simply be better at moving through ovarian fluid (Egeland et al. 2016); however, the experiment could not disentangle the two competing hypotheses. Makiguchi et al. (2016b) found that ovarian fluid differentially affects the sperm of precocious parr and anadromous masu salmon (Oncorhynchus masu). Based on their results, they encourage further study on seminal protein in salmonids including genetic effects, biochemical mechanisms of reproductive success and the use of proteomics to identify relevant proteins. They also note the importance of including ovarian fluid in studies of fertilization dynamics.

\section{Mate choice and reproductive success in salmonids: what is known?}

\section{(a) Body size}

Throughout the animal kingdom, body size is known to affect mate choice and sexual competition with both males and females generally demonstrating a preference for larger bodied mates (e.g. Ryan 1980; Côte and Hunte 1989; Howard et al. 1998; Aquiloni and Gherardi 2008). Male preference for female body size is thought to be driven, at least in part, by the ability of larger females to produce more eggs compared to smaller females. Moreover, larger females may outcompete smaller females for access to resources including nesting habitat (Fleming and Gross 1994). Furthermore, larger females can also better defend their nests, compared to smaller females (Van den Berghe and Gross 1984). Females demonstrate preferences for larger males even in instances when males provide no direct resources such as food, shelter or parental care (e.g. Auld et al. 2016). In non-resource based mating systems larger males may provide an indirect benefit of advantageous genes for offspring (e.g. Calsbeek and Sinervo 2002). While individuals in a wide array of taxa often prefer relatively large mates, there may be disadvantages to this preference including increased competition for the most desirable mates. For example, because large females are preferred by many males, there is a greater risk of males incurring both pre-mating competition for access to large females and post-mating sperm competition. As a result, males do not always exhibit a preference for larger females over smaller ones. In many populations, there remains variation in both male (e.g. Godin and Auld 2013) and female (e.g. Endler and Houde 1995) preference for body size.

Body size is one of the best-studied mate choice preferences in salmonids. There are multiple studies wherein male salmonids demonstrate a preference for large females as mates (e.g. Hanson and Smith 1967; Sargent et al. 1986; Foote 1988; Maekawa et al. 1994; Serbezov et al. 2010) (Table 1) as they are presumably more fecund and will therefore have increased 
reproductive output (e.g. Van den Berghe and Gross 1989); however, this is not always the case (Garant et al. 2001; Dickerson et al. 2005). Larger females are also capable of digging deeper redds (e.g. Quinn and Foote 1994; Steen and Quinn 1999) which has the advantage of decreasing the likelihood of gravel damage to eggs during heavy runoff (Van den Berghe and Gross 1984) or another female excavating the redd (Hanson and Smith 1967), improving chances of juvenile survival. Similarly, female salmonids generally prefer to mate with larger males (e.g. Foote 1989; Maekawa et al. 1994; Berejikian et al. 2000; Neff et al. 2008; Serbezov et al. 2010) (Table 1). In general, larger males produce more sperm (e.g. Watanabe et al. 2008) and are therefore able to fertilize a larger proportion of eggs (see Dickerson et al. 2005 for an exception), can outcompete smaller males for access to spawning females (e.g. Thomaz et al. 1997), and they may also have increased energy reserves to perform courtship displays, which can be attractive to females. For example, larger Arctic charr males invest more in courtship behaviours towards females compared to smaller males (Bolgan et al. 2017). Furthermore, larger males may have 'good' genes they will pass on to their offspring giving them a competitive advantage in growth and reproduction with larger females producing more eggs and larger males being more competitive for access to females. Despite these general trends, variation in mate choice among salmonids remains. For example, large brown trout females prefer to spawn with males larger than themselves while smaller females prefer mates of similar size (Labonne et al. 2009) and the effect of adult body size on the production of offspring in steelhead (Oncorhynchus mykiss) trout varies from year to year (Seamons et al. 2004). Observed variation in mate choice for body size may result in part from prevailing environmental factors. For example, in coho salmon the benefit of larger body size in competing for access to spawning females can be context-dependent with the benefit decreasing as density increases (Fleming and Gross 1994). Mutual mate preference for large body size often leads to sizeassortative mating, which appears to be common in salmonids (Table 1). Despite some variation in preference for larger body (e.g. Fleming and Gross 1994), it is one of the most consistent preferences observed in salmonid mate choice.

\section{(b) Dominance}

Males often engage in contests, battles or displays to establish dominance that grants access to sexually receptive females. Other than in primates, there is consistent evidence that dominant or higher-ranking males achieve greater offspring production than do subordinate males (Ellis 1995). Increased juvenile offspring production for dominant males is observed in salmonid mating systems, wherein males often compete for a top place in the dominance hierarchy (Berejikian et al. 2001) (Table 1). In a controlled experimental study, wild coho males exhibited dominance over captive reared males in approximately $80 \%$ of trials (Berejikian et al. 1997). This behavioural difference would account for some of the differential reproductive success between adult wild and hatchery males in coho. In coho or other species, age may also affect dominance hierarchies, such as older male Alpine Whitefish on average holding higher dominance positions compared to younger males (Rudolfsen et al. 2008).

Despite the apparent advantage of dominant males in some salmonids with regard to egg fertilization, female brown trout do not always experience benefits via offspring quality from mating with larger and more dominant males (Jacob et al. 2007). Similarly, Figenschou et al. (2007) found no difference in larval length, yolk area or red yolk pigment between dominant and subordinate offspring of Arctic charr. Moreover, they found subordinate males sired more offspring than dominant males. A study on Chinook salmon demonstrated frequency dependent selection for success of adults, which more often occupy dominant positions in a hierarchy, than jacks (Berejikian et al. 2010). Together, these results suggest that the advantage of being a dominant male is not ubiquitous and raise questions regarding which conditions incur dominance benefits. Further investigation into factors influencing this variation is needed.

\section{(c) Density}

Density of potential mates and competitors can affect individual mate choice decisions and offspring production (e.g. Fleming and Gross 1994; Atwell and Wagner 2014). With access to multiple prospective mating partners, individuals can increase choosiness because they are more likely to encounter high quality 
and/or compatible mates compared to when there are relatively few potential mates (e.g. Dawkins 1969). Conversely, the presence of competing rivals can decrease an individual's ability to mate with preferred partners, with a disproportionate effect on less competitive individuals (Wong and Candolin 2005). The effect of density on mating behaviour (e.g. Mathisen 1962) and success has been documented in salmonids. For example, sneaker males mating at low densities or in the absence of dominant males can monopolize fertilization of a female's eggs, whereas at high densities or when dominant males are present, multiple sneaker males will fertilize some smaller proportion of eggs (Berejikian et al. 2010; Weir et al. 2012) (Table 1). Moreover, the operational sex ratio (OSR), which is the ratio of sexually mature males to sexually mature females, differs between spawning grounds and affects male reproductive behaviour (Quinn et al. 1996). Fleming and Gross (1994) also observed a negative correlation between density and the advantage of large body size for access to females. It is therefore important to incorporate measures of density and alternative mating tactics when assessing mate choice and reproductive success for a population at any given time. However, to our knowledge it is currently unknown if similar patterns occur in salmonids other than coho and Atlantic salmon. Experimental manipulation of density and OSR during spawning could provide further insight into the effects of density and sex ratio during spawning on reproductive success in salmonids.

\section{(d) Return time}

In birds and salmon that migrate to breeding habitat, the time of arrival on mating grounds can affect their likelihood of successfully reproducing (e.g. Tryjanowski et al. 2010). Female sockeye salmon who return to the spawning grounds earlier typically have the opportunity to gain access to better spawning habitat, and irrespective of size, both males and females who arrived on the spawning grounds early had longer opportunities for reproduction (Hendry et al. 2001) (Table 1). Similarly, pink salmon (Oncorhynchus gorbuscha) males that arrived earlier often held more dominant social positions and sired more offspring, but female reproductive success was not linked to return time (Dickerson et al. 2005). Another benefit of arriving early is avoidance of over ripening of eggs because this can reduce egg viability (De
Gaudemar and Beall 1998). However, in steelhead trout the effect of arrival time on offspring production varies from year to year although differences in sample size between years could have contributed to observed inter-annual variation between years (Seamons et al. 2004). Similar to other factors affecting mate choice and reproductive success, the influence of return time on the number of healthy offspring produced differs among species, contexts and over time.

\section{(e) Ornamentation}

Since Darwin, elaborate traits and conspicuous ornamentation have been a central focus in mate choice and sexual selection (Zahavi 1975). Bright colours and other costly traits are thought to signal 'good genes' in potential mates but (Pitcher and Neff 2007) found no relationship between sexually selected traits of a sire and the survival or growth of his offspring in Chinook salmon. While mate choice studies involving ornamental traits have traditionally focused on female preference for male ornaments, there is increasing evidence that males also use female ornamentation (e.g. colour) as a mate choice cue (Amundsen and Forsgren 2001). This evidence exists for salmonids as several studies have shown male and/ or female mate choice and/or offspring production linked to coloration (Table 1). For example, male sockeye salmon have demonstrated a mating preference for models of red females over green morphs (Foote et al. 2004). The use of female models in this experiment controls for other differences that may exist between natural females. The ability of red morphs to better sequester carotenoids from the environment via diet may be indicative of 'good genes' and drive this preference (Craig and Foote 2001). In Chinook salmon (O. tshawytscha), which has red and white morphs, (Lehnert et al. 2016b) found some assortative mating based on colour morph. In another study, male Chinook with brighter lateral blue/green hues sired more offspring compared to less bright males, when spawning in experimental channels (Neff et al. 2008); however, in other salmonids red coloration in males, contrary to expectation, was not associated with increased offspring production or higher quality offspring. Brown trout males with greater amounts of dark pigmentation sire more viable offspring compared to males with greater levels of carotenoid pigmentation (Wedekind et al. 2008) and 
their offspring were more resistant to parasitic infection (Jacob et al. 2010), suggesting that levels of dark, but not red, pigmentation may be valid signals of good genes. Similarly, male fertilization potential of Arctic charr was negatively correlated with red spawning coloration (Liljedal et al. 1999) and offspring of brightly coloured males showed no advantage in embryo survival or growth (Janhunen et al. 2011). Red coloration is positively correlated with offspring length, but only in smaller males (Eilertsen et al. 2009) suggesting an interaction between length and coloration. Increased red coloration in females was negatively correlated with their reproductive potential. Moreover, the offspring they produced were less viable compared to paler counterparts (Janhunen et al. 2011). It is unclear what is driving the differences in preference/offspring production related to colour in different species/populations or whether the observed variation is the result of different methodologies. In salmonids, an improved understanding of factors contributing to these differences will allow researchers and hatchery managers to better understand mate choice and incorporate these findings into breeding decisions and strategies.

Ornamental traits other than colour can signal good genes or otherwise be attractive to the opposite sex. Evidence of this in salmonids exists from studies of whitefish, where increasing size of breeding tubercles positively correlates with survival of eggs between 30 days post gamete release and time of hatching (Wedekind et al. 2001). In their study, there was also a significant interaction of maternal and paternal effects suggesting genetic incompatibility unrelated to tubercle length (Wedekind et al. 2001). Incorporation of genetics in whitefish mate choice studies would improve our understanding of the importance of these genetic compatibilities and allow researchers to design experiments that tease apart the effects of ornamentation on mate choice in these species. Additionally, offspring of highly ornamented males and females have higher swimming speeds, better predator avoidance, while offspring of highly ornamented females, but not males, were larger than the offspring of less ornamented females (Kekäläinen et al. 2010). Huuskonen et al. (2009) found a paternal effect only of first feeding in larval offspring, but found a maternal effect in swimming ability, contrary to Kekäläinen et al. (2010). Differences in study results may be attributed to evolutionary history of fish used in each study.
Huuskonen et al. (2009) used fish from Koitajoki River in eastern Finland while Kekäläinen et al. (2010) used fish from Oulujoki in western Finland. Small sample size may also have affected the observed outcome with eggs from only two females used in one experiment (Huuskonen et al. 2009). Investigation of biotic or abiotic factors contributing to observed differences and higher sample sizes would allow for more accurate recognition of patterns that shape mate choice in salmonid fishes.

\section{(f) Major histocompatibility complex}

Over the past decades there has been a lot of interest in the effect of immune system compatibility on mate choice in a wide array of vertebrates. The immune system is instrumental to survival and protection from infectious bacteria, viruses, and parasites that an individual will be exposed to throughout life. The role of major histocompatibility complex (MHC) in mate choice has been examined in various groups of salmonids with much variation among findings (Table 1). Several studies have concluded that Atlantic salmon choose mates dissimilar to themselves at MHC loci (Landry et al. 2001; Consuegra and de Leaniz 2008; Evans et al. 2012), but Yeates et al. (2009) found preferential selection for sperm with similar MHC alleles. Promerová et al. (2017) found no evidence for non-random fusion of gametes at MHC II. Weir et al. (2012) found sneaker males had greater fertilization success with eggs of MHC similar females. Few studies directly explore underlying mechanisms that explain these differences. A study on brown trout concluded females preferentially selected mates with intermediate differences in MHC (Forsberg et al. 2007) while another study found brown trout MHC dissimilar offspring were more parasite resistant (Jacob et al. 2010). A study of Arctic charr showed greater male fertilization success when heterozygous at MHC alleles (Skarstein et al. 2005). In Chinook, there is evidence that resistance to pathogens was increased for captive bred MHC heterozygotes and individuals who were outbred (Arkush et al. 2002), but tests of mate choice in the wild show conflicting results. Neff et al. (2008) found female Chinook preferentially mating with males dissimilar to themselves at MHC loci, but males in their study mated randomly at MHC loci. Conversely, Lehnert et al. (2016b) found assortative mating at 
MHC I-A1 and random mating at MHC II-B1. Evans et al. (2013) found male Chinook more aggressive towards females with whom they would produce offspring with high or low diversity at MHC class II and their offspring showed greater diversity at MHC class I. In coho salmon, mating preferences at MHC loci differed between fish of wild and hatchery origin and between years (Whitcomb et al. 2014).

While some observed differences in MHC based mate choice may be attributable to differences in methodology or sample size (Hoover and Nevitt 2016), collectively the findings of these studies suggest that mate preferences based on MHC compatibility may differ among populations (see contrasting findings from Landry et al. 2001; Consuegra and de Leaniz 2008; Evans et al. 2012 compared to Yeates et al. 2009), environmental conditions (Larson et al. 2016), and/or temporally (Evans et al. 2012). To better understand mate choice based on immune system compatibility and use this information to effectively manage breeding in hatcheries, we need improved understanding of the importance of observed variation and to develop testable hypotheses that verify MHC is indeed relevant to how individuals of different species and populations choose mates under different circumstances. A comprehensive meta-analysis and comparison of species, populations and environmental conditions at time of study may help explain the observed differences in MHC based mate choice in salmonids and other species.

\section{(g) Relatedness}

Many studies have addressed whether or not degree of relatedness to potential sexual partners affects mate choice in a variety of species. In many populations, individuals preferentially mate with non-kin presumably to avoid negative effects associated with inbreeding depression (see Pusey and Wolf 1996); however, this trend is not ubiquitous and individuals from some populations preferentially mate with kin (e.g. Bateson 1982).

Juvenile Atlantic (Brown and Brown 1992, Rajakaruna et al. 2006) and coho salmon (Quinn and Busack 1985), rainbow trout (Oncorhynchus mykiss) (Brown and Brown 1992) and brook charr (Salvelinus fontinalis) (Rajakaruna et al. 2006), and Arctic charr (Olsén et al. 1998) are able to distinguish kin versus non-kin, but there are only a few studies that test whether adults discriminate against or favor kin as mating partners in the wild (e.g. Landry et al. 2001; Garant et al. 2005) (Table 1) and those studies yielded inconsistent results. Garant et al. (2005) found genetic diversity amongst offspring and an increased number of mates led to higher offspring production in female Atlantic salmon, but only an increased number of mates led to higher offspring production in males of the same species. They concluded that females mated with more outbred males, but it is unclear whether the finding increased matings for outbred males was the result of intrasexual or intersexual competition or whether it was the result of pre-spawning selection (mate choice) or post-spawning selection (cryptic female choice or sperm competition). Further, it cannot be ruled out that other mate pairings were made and the offspring not viable. Landry et al. (2001) concluded that Atlantic salmon chose mates that were MHC dissimilar, but found no genome wide evidence that mate choice was a mechanism to avoid inbreeding. As above, the experimental design did not enable the authors to tease apart the mechanism of competition. Furthermore, results from studies on the effects of inbreeding on salmonid offspring also differ. Kincaid (1976) found that inbreeding (mating fullsibs) in rainbow trout resulted in crippled young and decreased survival compared to mating of outbred half-sibs. Alternatively, Turner et al. (2009) found no relationship with genome wide relatedness and survivability in Atlantic salmon. In this study, fish were mated randomly and survival was compared to parental relatedness, rather than categorically comparing survival of offspring between pairs of mates that were related and those that were unrelated.

Outbreeding can also be disadvantageous, especially for populations adapted to specific environments, but in some circumstances salmonids will mate with individuals from a different species. For example, female Atlantic salmon will mate with male brown trout (Castillo et al. 2010). Similar to inbreeding, effects of outbreeding in salmonids are variable. In masu salmon offspring production of dispersers was lower compared to individuals returning to their natal stream (Kitanishi and Yamamoto 2015) suggesting disadvantages may result from at least a certain level of outbreeding. A study on Chinook salmon found no evidence of outbreeding depression nor evidence of beneficial heterosis in examined traits (Lehnert et al. 2014). Similarly, Houde et al. (2010) found no effect 
of inbreeding or outbreeding in their study population of Atlantic salmon. Houde et al. (2011) evaluated the potential effects of inbreeding and outbreeding depression on three populations of Atlantic salmon and concluded the effects were population dependent (Table 1). They recommend that potential effects of inbreeding and outbreeding depression should be evaluated on a population-level basis. Although some inbreeding occurs naturally as a result of strong homing and return timing of spawning individuals (Wang et al. 2002), there are apparently no studies that test whether males and females preferentially choose to mate with more or less related individuals in Pacific salmon.

Together, these results suggest that the effects of inbreeding and/or outbreeding differ among species and/or populations. However, differences in results may also be due to differences in methodology (e.g. natural spawning versus artificial crosses). To tease apart which factors are contributing to the observed findings (e.g. differences between species, populations or methodology) there needs to be standardized testing of inbreeding either across species or testing of different methodologies within a single species or population. While these studies provide interesting results as to whether mating events produced offspring, they are unable to tease apart the mechanism that led to the production of offspring (e.g. pre or postspawning mechanisms). These questions could be explored by the incorporation of complementary behavioral tests of mate choice based on inbreeding. Further, it would be useful/interesting to test whether inbreeding affects not only survival of young, but ultimately whether they reach sexual maturity (Lehnert et al. 2014) and produce offspring.

\section{(h) Fins}

Recent work has demonstrated preference for fin size in some fishes. In medaka (Oryzias latipes) females prefer males with relatively longer anal and dorsal fins (Fujimoto et al. 2014) and in a cichlid (Pelvicachromis taeniatus) males prefer females with larger pelvic fins (Baldauf et al. 2010). In some species of salmonid there is evidence that the adipose fin is a sexually selected characteristic (e.g. Westley et al. 2008) and that females demonstrate a preference for males with larger adipose fins relative to body size (e.g. Järvi 1990; Petersson et al. 1999) (Table 1). The size of the adipose fins of Atlantic salmon males who occupy a subordinate place in the hierarchy shrink after several days of interactions with dominant males (Haugland et al. 2011) and so larger adipose fins may be indicative of a socially dominant male, which are generally better competitors for access to females and may also be preferred by females. It is still unknown whether this apparent preference for relatively larger adipose fins persists in other salmonids including Pacific salmon. Typically, Pacific salmon produced in hatcheries have their adipose fins clipped for identification (Van der Haegen et al. 2005). It is an important question as to whether a preference for larger adipose size, including competition with males completely lacking adipose fins, leads to greater offspring production/reproductive success for males with relatively larger adipose fins.

Recent evidence also shows a mechanosensory role for adipose fins in the catfish (Corydoras aeneus). The adipose fin of this catfish is highly sensitive and able to detect small changes in lateral fin deflection (Aiello et al. 2016). This line of evidence has led to the hypothesis that the adipose fin is able to detect changes in water flow or turbulence. In a study of caudal fin kinematics in steelhead trout, Reimchen and Temple (2004) found that amputation of the adipose fin showed the greatest effect on caudal fin kinematics in turbulent conditions. If the adipose is able to detect and provide information regarding water flow, its absence could affect a male's ability to properly position himself and time the release of gametes in a mating situation in a flowing stream.

Similarly, there is evidence that the female anal fin is a secondary sexual characteristic in kokanee salmon (Oncorhynchus nerka) as it grows larger when females become sexually mature; however, because the female anal fin is often in the gravel during nest digging, it is unlikely to influence male preference, but may assist in egg deposition (Thorn and Morbey 2016). This fin enlargement did not occur with pectoral or pelvic fins at maturity. It is unknown whether this enlargement of the anal fin is consistent across salmonid species and populations or whether it is dependent on other external factors.

Incorporation of genetic analyses could provide further insight into whether the absence and/or size of an adipose fin affects male and female reproductive success and whether males incur a reproductive 
benefit of mating with females with larger anal fins in the wild.

\section{(i) Life history}

Assortative mating can occur based on behaviours and life history strategies. For example, melon flies (Bactrocera cucurbitae) mate assortatively based on development duration (Miyatake and Shimizu 1999). Assortative mating with respect to life history strategies also occurs within at least some (e.g. Foote and Larkin 1988), but not all (see Thériault et al. 2007), salmonid mating systems. Some species of salmonid exhibit distinct morphs (e.g. Hendry and Quinn 1997; Moreira and Taylor 2015) and life history strategies (e.g. sockeye and kokanee), including different spawning morphotypes (e.g. beach, stream, or glacial (Ramstad et al. 2010)), which can lead to reproductive isolation (Hendry et al. 2000). For example, individuals that spawned in streams instead of lakes had half the offspring production as natal stream spawners. There was no difference in offspring production of stream spawners who did not spawn in their natal stream compared to those spawning in their natal stream suggesting the reduced lifetime offspring production of lake spawners may be attributable to differences in morphotypes between lake and stream spawners (Peterson et al. 2014) (Table 1). This suggests the possibility of genetic or behavioural differences that result in lowered egg survival of lake spawners in faster flowing streams. For example, in fast flowing stream environments there may be increased payoff for females to increase the depth of their redds to prevent eggs from being swept away in the current. Due to differences in stream flow there may also be different selective pressures of sperm characteristics such as velocity and longevity. It is unknown whether finer scale differences in stream characteristics, such as velocity and depth, lead to assortative mating within habitats as well as between habitats. Fine-scale differences in optimal spawning habitat could be important in maintaining genetic diversity within populations.

\section{Future directions and priorities}

There are multiple factors known to influence mate choice in other species that have not yet been tested as a mechanism of mate choice in salmonids, including personality, cognition, predation, and gene drive. As such, there remain many unresolved questions involving mate choice in salmonids that could be important not only for our general understanding of mate choice in salmonids and potentially other polypoid species, but that could also contribute to improved conservation and hatchery practices. For the remainder of this review we will discuss (i) topics relevant to mate choice studies that have not been well studied in salmonids, but could potentially affect sexual competition in salmon (ii) the need for integration of different methodologies to enable a broader understanding of the factors that affect mate choice in salmonids and the underlying mechanisms, including what is driving observed differences in sexual competition between individuals, populations and species, and (iii) testable theory related to if and how mate choice patterns are impacted by increased ploidy.

Relatively unexplored topics in salmonid mate choice

\section{(a) Condition}

The state or condition of individuals can affect mating effort, mating preferences, attractiveness to others, gamete quality, and ultimately reproductive success (Bakker et al. 1999; Hebets et al. 2008; Schultzhaus et al. 2017; Evans et al. 2017). An individual's overall condition is influenced by factors including, but not limited to, diet (e.g. Schultzhaus et al. 2017), and parasite load (Hamilton and Zuk 1982). The effect of parasites on fish behaviour has been relatively well studied. Studies have shown that parasite infection can affect fish behaviour in multiple ways including altering their mate choice (Lopez 1999; Mazzi 2004) and an individual's likelihood of being selected as a mate (Milinski and Bakker 1990; Barber et al. 2000). Parasitic infection can diminish an individual's nutrition and energy reserves causing a decrease in attractive signals such as colour (Hamilton and Zuk 1982) and/or in reproductive effort including performing fewer courtship displays (e.g. Kennedy et al. 1987; Pélabon et al. 2005). Infection of visible parasites or changes in behaviour also signal the health of an individual's immune system to prospective mates who may choose to reject mates based on 
infection (Zahavi 1975). Furthermore, parasitic infection can impact male reproductive success by negatively affecting ejaculate quality (e.g. Liljedal et al. 1999; Kekäläinen et al. 2014). Because sperm is genetically different to one's self, the body will initiate an immune response towards it. Therefore, males may benefit from immune system suppression to protect their sperm prior to ejaculation (Liljedal et al. 1999; Skau and Folstad 2005); however, immune system suppression in males with infection may not be beneficial for their own survival. In salmonids, male Arctic charr with high levels of infection produced lower quality ejaculates compared to uninfected individuals. Males who resist parasite infection may therefore be able to produce higher quality ejaculates (Liljedal et al. 1999). We are unaware of any other studies that explicitly test how parasite infection affects mate choice in salmonids.

\section{(b) Predation}

Change in predation pressure can affect mate choice, mating behaviour, and sexual selection (Andersson 1994). This effect has been documented in insects (e.g. Hedrick and Dill 1993), amphibians (e.g. Tuttle et al. 1982), and fish (e.g. Endler 1987; Johnson and Basolo 2003). Because showy ornaments and displays are conspicuous and attract the attention of potential predators, in high predation environments selection should favor males who are less conspicuous and/or strategically adjust courtship displays in the presence of predators. For example, in the presence of a predator, male guppies from a high predation environment altered their conspicuous courtship displays whereas those from a low predation population did not adjust their courtship displays according to predation risk (Magurran and Seghers 1990). Changes in ambient predation pressure can affect mate choice and reproductive success by increasing predation on certain phenotypes over others, such as more conspicuous males.

Salmonids play an important role in ocean, freshwater and terrestrial ecosystems as an important food source for other species including bears (Ursus species) (e.g. Hilderbrand et al. 1999), marine mammals (e.g. Keefer et al. 2012; Wasser et al. 2017), birds (e.g. Quinn and Buck 2001), and humans. These predation pressures can cause selection on morphological and behavioural characteristics related to mating and reproductive success. This effect is documented in sockeye salmon (Quinn and Kinnison 1999; Quinn et al. 2001). Several studies reported that variation in predation pressure led to size selective mortality within and between populations (Quinn and Kinnison 1999; Quinn et al. 2001 Quinn and Buck 2001) with avian predators mainly targeting females and smaller fish and bears targeting males and larger fish. Predation from brown bears (Ursus arctos) was typically higher in smaller, shallow streams. With greater predation pressure from brown bears in these streams typical dominance of larger males for access to females was not observed (Quinn et al. 2003). Size selective fishing by humans can also affect OSR and opportunity for sexual selection (Kendall and Quinn 2013). Because populations are subject to different predators spatially and temporally (Keefer et al. 2012) effects of predation on sexual competition and reproductive success likely differ according to location, composition of predator populations, and timing; however, we do not know of any studies that directly compare salmonid mate choice in the presence or absence of predators or examine the effect of predator composition or density on mate choice. Understanding how predation shapes mate choice in salmonids will provide a better overall understanding of the factors affecting individual reproductive success in different environments.

\section{(c) Gene drive}

Selfish genetic elements (SGEs) (e.g. transposable elements, meiotic drivers, post segregation killers) (Werren 2011), ubiquitous in eukaryotes, frequently result in reproductive incompatibility that can lead to reduced reproductive success in males (Price and Wedell 2008; Lindholm et al. 2016). SGEs occur more than would be expected by chance in gametes and/or offspring and are associated with costs such as reduced fertility and sex bias in offspring (Wedell 2013). There is some evidence that individuals can avoid potential mates that may transmit SGEs by using morphological characteristics (Wilkinson et al. 1998) or odor cues (Lenington 1991). One example of a morphological trait associated with gene drive (the system that enables the increased transmission of SGEs) is the length of eyestalks in stalk-eyed flies (Diopsidae) (Wilkinson et al. 1998). There is also evidence from mice (Mus musculus) that sperm competition can suppress gene drive; however, it is not known whether 
this type of selection against gene drive happens at the gamete level in polyploids, which have different inheritance patterns than diploid individuals. If gene drive is occurring in salmonids, lack of sperm competition in some artificial breeding designs could be producing hatchery males with SGEs that are later avoided by females (Manser et al. 2017). While identification of SGEs is difficult, new technologies are helping move the field forward and new insights are being made. An improved understanding of SGEs and how they impact mate choice decisions and genetic inheritance in salmonids will help resolve theoretical questions surrounding SGEs in polyploids in general and provide insight into improved breeding practices for commercially important polyploid species, including salmonids.

\section{(d) Epigenetics}

Over the last two decades, there has been an increased interest in epigenetic effects on animal behaviour (e.g. Weaver et al. 2004; Curley et al. 2011), including reproductive behaviours (Crews et al. 2007), and offspring performance (e.g. Ducatez et al. 2012; Mashoodh et al. 2012; Valtonen et al. 2012). These epigenetically mediated changes are frequently the result of genome methylation and have been documented in insects (e.g. Crean et al. 2014), fish (e.g. Taborsky et al. 2013), and mammals (e.g. Crews et al. 2007; Jašarević et al. 2011; Skinner et al. 2014). They can influence the development of sexually selected characteristics (e.g. Jašarević et al. 2011, 2012) including behaviours such as courtship (Jašarević et al. 2012). Importantly, these epigenetic changes are heritable. For example, exposure to an endocrinedisrupting chemical can alter mate preferences in mice for three generations (Crews et al. 2007).

For external fertilizers, such as salmonids, and possibly some internal fertilizers, the recent pre-and post-release environments of sperm can affect its phenotype and the phenotype of any resultant offspring (see Marshall 2015 for a review). For example, the marine invertebrate broadcast spawner, Galeolaria gemineoa, produce offspring that are more resistant to hyposalinity when the sperm that sired them were also exposed to a similar hyposalinity (Ritchie and Marshall 2013). These epigenetic changes could have important implications for salmonids bred and/or reared in artificial environments during captivity, their gametes and/or offspring are likely exposed to different compounds and/or different concentrations of compounds than they would in a completely wild experience. A recent study by Le Luyer et al. (2017) demonstrated differences in genome methylation between hatchery and wild coho. Areas of the genome showing differences in methylation include genes related to salinity tolerance and behaviour, amongst others. Hatchery induced epigenetic changes such as those identified by Le Luyer et al. (2017) could affect mate choice decisions over subsequent generations in salmonids. For a comprehensive understanding of the factors affecting mate choice in salmonids, including differences between wild and captive bred individuals, we need to better understand how epigenetic changes affect their mating behaviour, mate choice and reproductive success.

\section{(e) Cognition}

Teleost fish display individual variation in cognitive abilities with sources of variation including sex differences, personality and degree of brain lateralization, which are heritable (Lucon-Xiccato and Bisazza 2017). Cognitive differences could contribute to individual differences in the ability to achieve fertilizations that produce offspring which survive to maturity. In vertebrates, including fishes (Shohet and Watt 2009), females often prefer to mate with males with good cognitive abilities (Boogert et al. 2011). In addition to being preferred by females, improved cognitive abilities could help individuals make good mate choice decisions and/or enhance their ability to compete intrasexually.

Recently, the effects of social competence and plastic behaviour on fitness have been gaining attention (Taborsky and Oliveira 2012). With respect to mate choice, socially competent individuals would be able to accurately assess their own ability to compete for females and direct efforts strategically. Because environmental change has been linked to enhanced cognitive abilities (e.g. Kotrschal and Taborsky 2010) and many salmonid habitats are currently undergoing rapid human induced environmental change (Gross 1991; Sih et al. 2011), it is important to understand if/ how environmental change can alter mate choice and reproductive success of salmonids.

Most fish reared in a hatchery experience a less stimulating and more crowded environment than is typical for wild fish during early life. There is evidence 
that cognitive, swimming (e.g. (Ahlbeck Bergendahl et al. 2017), foraging (Brown et al. 2003; Rodewald et al. 2011)), and other abilities are decreased when reared in less complex (e.g. Brown et al. 2003; Salvanes et al. 2013; DePasquale et al. 2016) and more crowded environments (Brockmark et al. 2010, but see Näslund et al. 2017). Research on other species has further suggested that the method of sensory (i.e. visual, chemical, or auditory) enrichment may have long-lasting effects on the ability of individuals to learn using specific sensory systems (Dolivo and Taborsky 2017). These hypotheses should be tested in salmonids to explore whether rearing in more complex environments also improves the reproductive success of hatchery fish. Because there is evidence that differences in personality and cerebral lateralization are at least in part heritable, a greater understanding of their genetic basis in salmonids will give us a better understanding not only of salmonid relative reproductive success, but also of the evolution of cognition in polyploids.

\section{(f) Personality}

Individuals often prefer certain behavioural characteristics in mates including elaborate courtship displays and innate personality traits, which are consistent across contexts and repeatable over time, such as boldness; however, preference for boldness is not consistent through the animal kingdom. For example, female guppies prefer to mate with bolder males (e.g. Godin and Dugatkin 1996), but female rainbow kribs (Pelvicachromis pulcher) preferentially mate with males who display a dissimilar level of boldness to themselves (Scherer et al. 2017), and pairs of great tits (Parus major) that mated assortatively at either extreme of the boldness spectrum had the greatest reproductive success (Both et al. 2005). A meta-analysis by Smith and Blumstein (2008) on multiple taxa, including fishes, found a significant positive correlation between boldness and reproductive success in captive animals. This relationship was significant for both males and females in captivity, but was found to be strongest for captive males. Fleming et al. $(1996,1997)$ found first-generation hatchery bred Atlantic salmon were bolder compared to wild counterparts. Further research is needed to understand the variation in preference for personality and whether differences in personality play a role in salmonid mate choice and reproductive success.

Personality traits such as boldness are also correlated with an individual's likelihood of using social information during decision-making such as strategically adjusting their mate choice in the presence of an audience of sexual competitors (Bierbach et al. 2015). Since social information can provide important and energetically inexpensive information regarding the quality of potential mates, differences in personality could further affect an individual's ability to make good mate choice decisions that lead to increased reproductive success; however there have been few studies on the effect of behavioural traits and individual personality on reproductive success in salmonids despite observations that this taxon displays repeatable personality characteristics (e.g. Sneddon 2003; Wilson and Stevens 2005; Adriaenssens and Johnsson 2010) that are heritable (Vilhunen et al. 2008; Kortet et al. 2014) and evidence that personality can affect mate choice (e.g. Godin and Dugatkin 1996; Both et al. 2005; David and Cézilly 2011; Scherer et al. 2017).

\section{(g) Courtship}

Males who perform acts of courtship such as presentation of nuptial gift, performance of song or elaborate displays are often preferred by females in polygamous mating systems wherein males compete for access to sexually receptive females (Andersson 1994); however, courtship is energetically costly and often highly conspicuous to nearby predators. An alternative tactic to achieve fertilizations is sneak mating attempts. In general, sneak mating secures a lesser proportion of fertilizations compared to males who perform courtship acts (e.g. Berejikian et al. 2010). Differential fertilization success may be a function of female preference since sneaker males have greater gonad investment (e.g. Vladić et al. 2010), and more competitive sperm (e.g. greater velocity) (Rudolfsen et al. 2006; Young et al. 2013), although it is often released after that of courting males (e.g. Sørum et al. 2011).

Upon arrival at spawning grounds, both male and female salmonids engage in distinct pre-mating behaviours including female redd digging and male courtship. Exhibition of these behaviours can signal to potential mating partners and other conspecifics about 
an individual's quality (e.g. fecundity) and readiness to spawn. Pre-mating behaviours include males approaching females, darting towards nest-digging females, hovering nearby, quivering and crossing over (reviewed in Esteve 2005) (Fig. 1a). Female status and behaviour affect male courtship displays. For example, male Atlantic salmon perform more courtship displays towards females digging redds (De Gaudemar et al. 2000) and masu salmon and Biwa salmon (Oncorhynchus rhodurus) perform more courtship displays towards females who had recently ovulated (Honda 1982). Aside from the study of De Gaudemar et al. (2000) showing that female Atlantic salmon prefer males based on intensity of courtship, there do not appear to be any studies that investigate how female preference for males varies according to duration and quality of courtship displays performed.

A genetic basis of courtship behaviour has recently been identified in Drosophila (e.g. Yamamnoto and Koganezawa 2013). An understanding of the genetic basis of pre-mating behaviours and courtship in salmonids including differences in genetic makeup and gene expression could provide important insight into variation in reproductive success and mate choice.

\section{(h) Social factors}

While the majority of research on mate choice and reproductive success has focused on morphological traits such as body size and coloration, there is growing evidence that one's social environment (e.g. individuals within signaling and receiving distance), and interactions with others, aside from prospective mates, can affect mate choice, sexual competition and thus reproductive success (e.g. Gröning and Hochkirch 2008). Extensive evidence that social factors are important to mate choice exists in amphibians (e.g. Hettyey and Pearman 2003), birds (e.g. White and Galef 1999), fish (e.g. Oliveira et al. 2002; Hesse et al. 2016), and mammals (e.g. Perret 1992). Because in most instances salmon spawn in the presence of multiple individuals and will compete directly with others for access to breeding locations and high quality mates, the social environment is likely relevant to mate choice in salmonids. One's social environment also provides opportunity for individuals to learn about prospective mates and competitors from observing the behaviour and interactions of others (Valone and Templeton 2002; Witte 2006; Grosenick et al. 2007).

In natural social networks fish are able to eavesdrop on the interactions of others when their own personally acquired information may not be reliable or it is too expensive to adequately sample all potential resources. One social phenomenon that may be especially interesting in relation to salmon mate choice is mate choice copying. There is a large body of evidence that female insects, birds, fish, and mammals will use social information to assess the quality of potential mates and copy the mate choice of other females (see Vakirtzis 2011 for a review). An increasing number of studies also demonstrate mate choice copying by males (e.g. Schlupp and Ryan 1997; Auld and Godin 2015). Copying the mate choice of another male increases sperm competition for both males, but that cost may be offset for the copier by reduced costs of sampling females. To avoid being copied and the subsequent increase in sperm competition males can either alter their mate choice, change their behaviour to conceal their true mate choice or avoid competition (e.g. Schlupp and Ryan 1997; Auld and Godin 2015). In Trinidadian guppies, this change in mating behaviour is strongest in the presence of larger, more competitive rivals (Auld et al. 2017). In salmonids, chemicals released that can influence spawning behaviour in the opposite sex could also provide information to intrasexual competitors (e.g. Arctic charr, Sveinsson and Hara 1995; rainbow trout, Yambe and Yamazaki 2001).

In other species, familiarity with potential mates can also affect mate choice with individuals preferentially mating with or avoiding familiar individuals (reviewed in Cheetham et al. 2008). Avoidance of mating with familiar individuals is evident in insects (e.g. fruit flies, Drosophila melanogaster, Ödeen and Moray 2008), reptiles (brown anole, Anolis sagrei, Tokarz 1992), and live-bearing fish (guppies, Hughes et al. 1999). Conversely, medaka fish (Okuyama et al. 2014) and giant kangaroo rats (Dipodomys ingens) (Randall et al. 2002) preferentially mate with familiar individuals. Familiarity with potential mates allows individuals to make mate choice decisions based on accumulated personally acquired information while mating with unfamiliar individuals may reduce risk of inbreeding and/or introduce novel genes into the population. However, aside from studies on the effect of density in coho (Fleming and Gross 1994) and 
Atlantic salmon (Weir et al. 2012), and the effect of social environment in rainbow trout (Rouger and Liley 1993; Liley et al. 2002) (see Table 1) we are not aware of any studies that examined the effect of the social environment on salmonid mating behaviour even though in other contexts salmonid behaviour can be affected by social environment. For example, Arctic charr learn anti-predator behaviours from conspecifics (Vilhunen et al. 2005). Given this ability of salmonids to use social information, we should explore potential use of social information in a mating context including possibilities of mate choice copying and audience induced changes in mating behaviour of salmonids.

\section{Mechanisms and trends}

There are pros and cons to the different methodologies used in the studies discussed in this review. Many studies did not actually test behavioural mate choice, but rather inferred mate choice from genotypes of offspring (e.g. Landry et al. 2001; Forsberg et al. 2007). While the ultimate production of viable offspring is important, and survival offspring to sexual maturity is the true measure of an individual's fitness, it provides little insight to the mechanisms leading to the production of those offspring. For instance, it is possible that individuals made other mate choice decisions that did not result in successful fertilizations or survival of offspring. Studies that used natural spawning events in river systems and inferred mate choice from the genotypes of juvenile offspring produced have the advantage of most closely mimicking conditions in the wild. However, this method makes it difficult to determine whether the observed mate pairs are the result of inter- or intra-sexual competition and whether selection is happening before or after spawning.

Some new insights into the mechanism of selection can be gained from controlled mate choice experiments in artificial stream channels. Using artificial stream channels allows for more control of potentially confounding factors and facilitates behavioural observations, but at the expensive of a less natural environment. Finally, stripping gametes for artificial fertilizations allows for very controlled studies of sperm competition and gamete choice, but has the disadvantage of gametes being damaged in the process (e.g. Campbell et al. 1992). It is important to pursue questions related to mate choice in salmonids and polyploids in general, using traditional methodologies, such as behavioural studies together with novel methodologies, including the incorporation of genetic techniques, transcriptomics and proteomics (Makiguchi et al. 2016b; Gombar et al. 2017) within the same system. The complementary use of methodologies within a single system may allow researchers to answer questions related to mating behaviour and reproductive success that would not be possible with traditional behavioural studies (Archie and Chiyo 2011). The use of these techniques together with behavioural studies may shed light on the mechanisms driving patterns of mate choice in polyploids observed in nature.

Mate choice decisions can be plastic and contextdependent (e.g. Gauthey et al. 2016), being influenced by the environment including abiotic and biotic conditions such as predation and the social environment. It is therefore important to not just consider current mate choice decisions in one scenario or point in time, but to identify trends and understand how they vary across time and environments. This understanding is particularly important because environmental change of today is demonstrating striking extremes and rates of flux across habitats. Sustainable practices, therefore, needs to learn more about the interface of these variable phenomena (mate choice and climate), including new response to unprecedented states, in order that our futures remain resilient. Determining trends in salmon mate choice and how mate choice varies with environmental conditions should be a priority. Among salmonids, certain groups are underrepresented in the current body of literature on salmonid mate choice and reproductive success (e.g. taimen, long-fin charr, round whitefish (Prosopium cylindraceum), lenoks). Further study on these species/populations could provide greater insight into patterns of reproductive success. The use of metaanalyses and comparative studies to determine underlying patterns that contribute to the variation of mate choice and reproductive success in salmonids, including finer scale differences within populations will be useful to determining the underlying mechanisms that are driving the different mate choice patterns seen in different species, populations, and studies.

Finally, many of the aforementioned studies used the production and/or survival of juvenile offspring, as a proxy of mate choice and/or RRS, which, while informative and an important measure, does not 
provide information regarding the survival of those offspring to sexual reproduction themselves (i.e. fitness). In instances where studies of mate choice are being undertaken to improve conservation and/or hatchery practices, it is useful to know whether the offspring produced survive to reproduce themselves. Given that salmonids do not reach sexual maturity for several years, this would require investment into the implementation of multi-year studies.

\section{Additional complexities owing to ploidy}

Extensive literature on the evolutionary significance of polyploidy among plants holds that (1) polyploids have higher levels of heterozygosity, (2) are less inbred and (3) experience genome rearrangements more commonly than their diploid counterparts (Soltis and Soltis 2000). This raises a number of interesting questions for mate choice. However, mate-choice studies in plants are rare and the few existing studies focus largely on pre-zygotic mechanisms among gametes and associated reproductive organs rather than behaviour (Wilson and Burley 1983; Marshall and Ellstrand 1988). Other research notes that polyploidy is less prevalent in the animal kingdom; notable exceptions include amphibians and fish where complete lineages, including salmonids are of relatively recent polyploid origin (Zhou et al. 2002; Le Comber and Smith 2004; Mable et al. 2011). Indeed, some have pointed to the notion that a ploidy shift may have provided genomic innovations that enabled development of anadromous life histories expressed among salmonids (Allendorf and Thorgaard 1984; Mable et al. 2011). Intriguing research exploring whether ploidy variance among insects may indeed provide innovation for evolution of highly social honeybees (Chau and Goodisman 2017) has yet to be fully explored.

Studies such as these raise question as to whether ploidy shifts observed among salmonids may have opened new doors for the development of socially based aspects in this group, including those related to mate choice mentioned above. Returning to more basic considerations, salmonid tetrasomy raises a pressing question for mate choice: genetic variation is potentially doubled among mates, yet only an unknown fraction of this variation is actually expressed. How is this unknown 'boon' of heritance accounted for as partners make choices? While, this issue occurs among diploid species to some extent because of dominance, and partners always risk the gamble of which actual allele will occur in the gametes they and their partner(s) contribute to fertilized zygotes they share, in tetraploid species, gametes may contain two alleles for paralogous loci. Given greater chances of genomic rearrangement noted above, how do mate choice decisions account for these increasing aspects of variability? Some studies have provided evidence for use of sound and/or odors as means of attaining ploidy-specific assortative mating in amphibians (Keller and Gerhardt 2001; Mable et al. 2011) and note that it would be interesting to determine whether mate choice by ploidy exists among fish and underlying mechanisms. We, however, are not aware of any literature that has broached our question about how to account for, or gamble with increasing levels of variability, likely among polyploid mate choice scenarios. Development of mate choice models that incorporate increased levels of ploidy and the use emergent experimental gene silencing using CRISPR-Cas9 technologies in empirical studies may illuminate some of these issues. Resolving these questions in salmonids could further shed light on mate choice in other polyploid fishes such as sturgeon (Acipenseridae) and some carp (Cyprinidae) (Leggatt and Iwama 2003).

Application and importance for salmonid aquaculture, conservation, and management

There is a growing body of evidence that mate choice is important for offspring production in captive contexts, with greater offspring production for individuals who were able to choose their own mates compared to individuals who could not (see MartinWintle et al. 2018 for a review). In salmon aquaculture, individuals are not given the opportunity to select their mates and in many instances, there is little to opportunity for post-copulatory sexual selection (e.g. cryptic female choice or sperm competition between potential sires). A more complete understanding of salmon mate choice and how this varies across context (species, climate and space) will better inform decisions related to mate pairings in a hatchery context. This and other improved hatchery practices that provide climate sustainable fitness to offspring will contribute to conservation and management strategies for more resilient futures. 


\section{Conclusions}

There is strong evidence of mutual mate choice in many salmonids; however, unresolved questions remain surrounding traits that affect mate choice and how those traits are affected by external factors such as changing environments, how they differ between populations and over time, and how those preferences affect reproductive success. Combining emerging technologies, including genetic techniques, with traditional behavioural studies can improve our insight into the mechanisms and maintenance of variation in behaviours including those related to mate choice. Answering these questions will propel forward our current knowledge about salmonid populations and help inform future fisheries management decisions. Moreover, it will shed light on the different inheritance patterns in tetraploids and the selective forces that drive speciation of salmonids.

Acknowledgements This work was funded by the Oregon Department of Fish and Wildlife. We gratefully acknowledge support from the Oregon Hatchery Research Center and the Department of Fisheries and Wildlife at Oregon State University. We thank Paul Vecsei for permission to include his images and Scott D. Lewis for comments on a previous version of the manuscript. We also thank the Associate Editor and two anonymous reviewers for their valuable comments which greatly improved the manuscript.

Open Access This article is distributed under the terms of the Creative Commons Attribution 4.0 International License (http:// creativecommons.org/licenses/by/4.0/), which permits unrestricted use, distribution, and reproduction in any medium, provided you give appropriate credit to the original author(s) and the source, provide a link to the Creative Commons license, and indicate if changes were made.

\section{References}

Adkins-Regan E, Krakauer A (2000) Removal of adult males from the rearing environment increases preference for same-sex partners in the zebra finch. Anim Behav 60:47-53

Adriaenssens B, Johnsson JI (2010) Shy trout grow faster: exploring links between personality and fitness-related traits in the wild. Behav Ecol 1:135-143

Ahlbeck Bergendahl I, Miller S, Depasquale C, Giralico L, Braithwaite VA (2017) Becoming a better swimmer: structural complexity enhances agility in a captive-reared fish. J Fish Biol 90(3):1112-1117

Aiello BR, Stewart TA, Hale ME (2016) Mechanosensation in an adipose fin. Proc R Soc B 283(1826):201521794
Allendorf FW, Thorgaard GH (1984) Tetraploidy and the evolution of salmonid fishes. In: Turner BJ (ed) Evolutionary genetics of fishes. Springer, New York, pp 1-53

Amundsen T, Forsgren E (2001) Male mate choice selects for female coloration in a fish. Proc Nat Acad Sci USA 98(23): 13155-13160

Andersson MB (1994) Sexual selection. Princeton University Press, Princeton

Andersson MB, Simmons LW (2006) Sexual selection and mate choice. Trends Ecol Evol 21:296-302

Aquiloni L, Gherardi F (2008) Mutual mate choice in crayfish: large body size is selected by both sexes, virginity by males only. J Zool 27(2):171-179

Araki H, Berejikian BA, Ford MJ, Blouin MS (2008) Fitness of hatchery-reared salmonids in the wild. Evol Appl 1:342-355

Archie EA, Chiyo PI (2011) Elephant behaviour and conservation: social relationships, the effects of poaching, and genetic tools for management. Mol Ecol 21:765-778

Arkush KD, Giese AR, Mendonca HL, McBride AM, Marty GD, Hedrick PW (2002) Resistance to three pathogens in the endangered winter-run Chinook salmon (Oncorhynchus tshawytscha): effects of inbreeding and major histocompatibility complex genotypes. Can J Fish Aquat Sci 59:966-975

Atwell A, Wagner WE (2014) Female mate choice plasticity is affected by the interaction between male density and female age in a field cricket. Anim Behav 98:177-183

Auld HL, Godin J-GJ (2015) Sexual voyeurs and copiers: social copying and the audience effect on male mate choice in the guppy. Behav Ecol Sociobiol 69(11):1795-1807

Auld HL, Pusiak RJP, Godin J-GJ (2016) Independent mating preferences for male body size and coloration in female Trinidadian guppies. Ethology 122(7):597-608

Auld HL, Ramnarine IW, Godin J-GJ (2017) Male mate choice in the Trinidadian guppy is influenced by the phenotype of audience sexual rivals. Behav Ecol 28(2):362-372

Aykanat T, Johnston SE, Orell P, Niemelä E, Erkinaro J, Primmer CR (2015) Low but significant genetic differentiation underlies biologically meaningful phenotypic divergence in a large Atlantic salmon population. Mol Ecol 24:5158-5174

Bakker TC, Künzler R, Mazzi D (1999) Sexual selection: condition-related mate choice in sticklebacks. Nature 401(6750): 234

Baldauf SA, Bakker TC, Herder F, Kullmann H, Thünken T (2010) Male mate choice scales female ornament allometry in a cichlid fish. BMC Evol Biol 10(1):301

Barber I, Hoare D, Krause J (2000) Effects of parasites on fish behaviour: a review and evolutionary perspective. Rev Fish Biol Fish 10:131-165

Bateson P (1982) Preferences for cousins in Japanese quail. Nature 295:236-237

Bentzen P, Olsen JB, McLean JE, Seamons TR, Quinn TP (2001) Kinship analysis of Pacific salmon: insights into mating, homing, and timing of reproduction. J Hered 92:127-136

Berejikian BA, Tezak EP, Schroder SL, Knudsen CM, Hard JJ (1997) Reproductive behavioral interactions between wild and captively reared coho salmon (Oncorhynchus kisutch). ICES J Mar Sci 54:1040-1050 
Berejikian BA, Tezak EP, LaRae AL (2000) Female mate choice and spawning behaviour of Chinook salmon under experimental conditions. J Fish Biol 57:647-661

Berejikian BA, Tezak EP, Park L, LaHood E, Schroder SL, Beall E (2001) Male competition and breeding success in captively reared and wild coho salmon (Oncorhynchus kisutch). Can J Fish Aquat Sci 58:804-810

Berejikian BA, Van Doornik DM, Endicott RC, Hoffnagle TL, Tezak EP, Moore ME, Atkins J (2010) Mating success of alternative male phenotypes and evidence for frequencydependent selection in Chinook salmon, Oncorhynchus tshawytscha. Can J Fish Aquat Sci 67:1933-1941

Bierbach D, Sommer-Trembo C, Hanisch J, Wolf M, Plath M (2015) Personality affects mate choice: bolder males show stronger audience effects under high competition. Behav Ecol 26:1314-1325

Birkhead TR, Møller AP (eds) (1998) Sperm competition and sexual selection. Academic Press, London

Bolgan M, O’Brien J, Picciulin M, Manning L, Gammell M (2017) Behaviour of Arctic charr Salvelinus alpinus during induced mating season in captivity: how male relative size influences male behavioural investment and female preference over time. J Fish Biol 90:1479-1505

Boogert NJ, Fawcett TW, Lefebvre L (2011) Mate choice for cognitive traits: a review of the evidence in nonhuman vertebrates. Behav Ecol 22:447-459

Both C, Dingemanse NJ, Drent PJ, Tinbergen JM (2005) Pairs of extreme avian personalities have highest reproductive success. J Anim Ecol 74(4):667-674

Bretman A, Fricke C, Chapman T (2009) Plastic responses of male Drosophila melanogaster to the level of sperm competition increase male reproductive fitness. Proc R Soc B 276:1705-1711

Brockmark S, Adriaenssens B, Johnsson JI (2010) Less is more: density influences the development of behavioural life skills in trout. Proc R Soc B 277(1696):3035-3043

Brown GE, Brown JA (1992) Do rainbow trout and Atlantic salmon discriminate kin? Can J Zool 70:1636-1640

Brown C, Davidson T, Laland K (2003) Environmental enrichment and prior experience of live prey improve foraging behaviour in hatchery-reared Atlantic salmon. J Fish Biol 63(s1):187-196

Calsbeek R, Sinervo B (2002) Uncoupling direct and indirect components of female mate choice in the wild. PNAS 99(23):14897-14902

Camarillo-Sepulveda N, Hamoutene D, Lush L, Burt K, Volkoff $\mathrm{H}$, Fleming IA (2015) Sperm traits in farmed and wild Atlantic salmon Salmo salar. J Fish Biol 88:709-717

Campbell PM, Pottinger TG, Sumpter JP (1992) Stress reduces the quality of gametes produced by rainbow trout. Biol Reprod 47:1140-1150

Candolin U (2003) The use of multiple cues in mate choice. Biol Rev 78:575-595

Castillo AG, Beall E, Morán P, Martinez JL, Garcia-Vazquez E (2010) Indirect benefits for female salmon from mating with brown trout. J Hered 101:461-468

Chau LM, Goodisman MA (2017) Gene duplication and the evolution of phenotypic diversity in insect societies. Evolution 71(12):2871-2884

Cheetham SA, Thom MD, Beynon RJ, Hurst JL (2008) The effect of familiarity on mate choice. In: Hurst JL, Beynon
RJ, Roberts SC, Wyatt TD (eds) Chemical signals in vertebrates 11. Springer, New York, NY

Consuegra S, de Leaniz CG (2008) MHC-mediated mate choice increases parasite resistance in salmon. Proc $\mathrm{R}$ Soc $\mathrm{B}$ 275:1397-1403

Côte IM, Hunte W (1989) Male and female mate choice in the redlip blenny: why bigger is better. Anim Behav 38(1):78-88

Craig KJ, Foote CJ (2001) Countergradient variation and secondary sexual color: phenotypic convergence promotes genetic divergence in carotenoid use between sympatric anadromous and nonanadromous morphs of sockeye salmon (Oncorhynchus nerka). Evolution 55:380-391

Crean AJ, Kopps AM, Bonduriansky R (2014) Revisiting telegony: offspring inherit an acquired characteristic of their mother's previous mate. Ecol Lett 17(12):1545-1552

Crews D, Gore AC, Hsu TS, Dangleben NL, Spinetta M, Schallert T, Anway MD, Skinner MK (2007) Transgenerational epigenetic imprints on mate preference. Proc Natl Acad Sci USA 104(14):5942-5946

Curley JP, Mashoodh R, Champagne FA (2011) Epigenetics and the origins of paternal effects. Horm Behav 59(3):306-314

David M, Cézilly F (2011) Personality may confound common measures of mate-choice. PLoS ONE 6:e24778

Dawkins R (1969) A threshold model of choice behaviour. Anim Behav 17:120-133

De Gaudemar B (1998) Sexual selection and breeding patterns: insights from salmonids (Salmonidae). Acta Biotheor 46(3):235-251

De Gaudemar B, Beall E (1998) Effects of overripening on spawning behaviour and reproductive success of Atlantic salmon females spawning in a controlled flow channel. J Fish Biol 53:434-446

De Gaudemar B, Beall E (1999) Reproductive behavioural sequences of single pairs of Atlantic salmon in an experimental stream. Anim Behav 57:1207-1217

De Gaudemar B, Bonzom JM, Beall E (2000) Effects of courtship and relative mate size on sexual motivation in Atlantic salmon. J Fish Biol 57:502-515

DePasquale C, Neuberger T, Hirrlinger AM, Braithwaite VA (2016) The influence of complex and threatening environments in early life on brain size and behaviour. Proc $\mathrm{R}$ Soc B 283:20152564

Dickerson BR, Brinck KW, Willson MF, Bentzen P, Quinn TP (2005) Relative importance of salmon body size and arrival time at breeding grounds to reproductive success. Ecology $86: 347-352$

Dolivo V, Taborsky M (2017) Environmental enrichment of young adult rats (Rattus norvegicus) in different sensory modalities has long-lasting effects on their ability to learn via specific sensory channels. J Comp Pyschol 131(2):79-88

Ducatez S, Baguette M, Stevens VM, Legrand D, Fréville H (2012) Complex interactions between paternal and maternal effects: parental experience and age at reproduction affect fecundity and offspring performance in a butterfly. Evolution 66(11):3558-3569

Eberhard WG (1996) Female control: sexual selection by cryptic female choice. Princeton University Press, Princeton 
Edward DA, Chapman T (2011) The evolution and significance of male mate choice. Trends Ecol Evol 26(12):647-654

Edward DA, Chapman T (2013) Variation in male mate choice in Drosophila melanogaster. PLoS ONE 8(2):e56299

Egeland T, Rudolfsen G, Nordeide JT, Folstad I (2015) On the relative effect of spawning asynchrony, sperm quantity and sperm quality on paternity under sperm competition. Front Ecol Evol 3:77

Egeland TB, Rudolfsen G, Nordeide JT, Folstad I (2016) Status specific tailoring of sperm behavior in an external fertilizer. Front Ecol Evol 4:135

Eilertsen EM, Bårdsen B-J, Liljedal S, Rudolfsen G, Folstad I (2009) Experimental evidence for paternal effects on offspring growth rate in Arctic charr (Salvelinus alpinus). Proc R Soc B 276:129-136

Ellis L (1995) Dominance and reproductive success among nonhuman animals: a cross-species comparison. Ethol Sociobiol 16:257-333

Endler JA (1987) Predation, light intensity and courtship behaviour in Poecilia reticulata (Pisces: Poeciliidae). Anim Behav 35(5):1376-1385

Endler JA, Houde AE (1995) Geographic variation in female preferences for male traits in Poecilia reticulata. Evolution 49(3):456-468

Esteve M (2005) Observations of spawning behaviour in Salmoninae: Salmo, Oncorhynchus and Salvelinus. Rev Fish Biol Fish 15:1-21

Evans ML, Dionne M, Miller KM, Bernatchez L (2012) Mate choice for major histocompatibility complex genetic divergence as a bet-hedging strategy in the Atlantic salmon (Salmo salar). Proc R Soc B 279:379-386

Evans ML, Neff BD, Heath DD (2013) Behavioural and genetic analyses of mate choice and reproductive success in two Chinook salmon populations. Can J Fish Aquat Sci 70:263-270

Evans JP, Lymbery RA, Wiid KS, Rahman MM, Gasparini C (2017) Sperm as moderators of environmentally induced paternal effects in a livebearing fish. Biol Lett 13(4):20170087

Falica BK, Lehnert SJ, Pitcher TE, Heath DD, Higgs DM (2017) Ontogenic shifts in genetic and maternal effects on length and survival in Chinook salmon (Oncorhynchus tshawytscha). Aquaculture 468(1):218-225

Figenschou L, Folstad I, Liljedal S (2004) Lek fidelity of male Arctic charr. Can J Zool 82:1278-1284

Figenschou L, Rudolfsen G, Folstad I (2007) Female Arctic charr do not show apparent benefits from exposing their eggs to sperm from dominant males. J Fish Biol 7:284-289

Fleming IA (1996) Reproductive strategies of Atlantic salmon: ecology and evolution. Rev Fish Biol Fish 6:379-416

Fleming IA, Gross MR (1992) Reproductive behavior of hatchery and wild coho salmon (Oncorhynchus kisutch): does it differ? Aqua 103:101-121

Fleming IA, Gross MR (1994) Breeding competition in a Pacific salmon (coho: Oncorhynchus kisutch): measures of natural and sexual selection. Evolution 48:637-657

Fleming IA, Petersson E (2001) The ability of released, hatchery salmonids to breed and contribute to the natural productivity of wild populations. Nord J Freshw Res 75:71-98

Fleming IA, Jonsson B, Gross MR, Lamberg A (1996) An experimental study of the reproductive behaviour and success of farmed and on wild Atlantic salmon (Salmo salar). J App Ecol 33:893-905

Fleming IA, Lamberg A, Jonsson B (1997) Effects of early experience on the reproductive performance of Atlantic salmon. Behav Ecol 8:470-480

Foote CJ (1988) Male mate choice dependent on male size in salmon. Behaviour 106:63-80

Foote CJ (1989) Female mate preference in Pacific salmon. Anim Behav 38:721-723

Foote CJ (1990) An experimental comparison of male and female spawning territoriality in a Pacific salmon. Behaviour 115:283-314

Foote CJ, Larkin PA (1988) The role of male choice in the assortative mating of anadromous and non-anadromous sockeye salmon (Oncorhynchus nerka). Behaviour 106:43-61

Foote CJ, Brown GS, Hawryshyn CW (2004) Female colour and male choice in sockeye salmon: implications for the phenotypic convergence of anadromous and nonanadromous morphs. Anim Behav 67:69-83

Forsberg LA, Dannewitz J, Petersson E, Grahn M (2007) Influence of genetic dissimilarity in the reproductive success and mate choice of brown trout-females fishing for optimal MHC dissimilarity. J Evol Biol 20:1859-1869

Fraser DJ (2008) How well can captive breeding programs conserve biodiversity? A review of salmonids. Evol Appl 1(4):535-586

Fujimoto S, Kawajiri M, Kitano J, Yamahira K (2014) Female mate preference for longer fins in medaka. Zool Sci 31(11):703-708

Gage MJG, Macfarlane CP, Yeates S, Ward RG, Searle JB, Parker GA (2004) Spermatozoal traits and sperm competition in Atlantic salmon: relative sperm velocity is the primary determinant of fertilization success. Curr Biol 14:44-47

Galvano PM, Johnson K, Wilson CC, Pitcher TE, Butts IA (2013) Ovarian fluid influences sperm performance in lake trout, Salvelinus namaycush. Reprod Biol 13(2):172-175

Garant D, Dodson JJ, Bernatchez L (2001) A genetic evaluation of mating system and determinants of individual reproductive success in Atlantic salmon (Salmo salar L.). J Hered 92:137-145

Garant D, Dodson JJ, Bernatchez L (2005) Offspring genetic diversity increases fitness of female Atlantic salmon (Salmo salar). Behav Ecol Sociobiol 57:240-244

Garner SR, Bortoluzzi RN, Heath DD, Neff BD (2010) Sexual conflict inhibits female mate choice for major histocompatibility complex dissimilarity in Chinook salmon. Proc R Soc B 277:885-894

Gauthey Z, Hendry AP, Elosegi A, Tentelier C, Labonne J (2016) The context dependence of assortative mating: a demonstration with conspecific salmonid populations. J Evol Biol 29:1827-1835

Godin J-GJ, Auld HL (2013) Covariation and repeatability of male mating effort and mating preferences in a promiscuous fish. Ecol Evol 3(7):2020-2029

Godin J-GJ, Dugatkin LA (1996) Female mating preference for bold males in the guppy, Poecilia reticulata. Proc Nat Acad Sci USA 93:10262-10267

Gombar R, Pitcher TE, Lewis JA, Auld J, Vacratsis PO (2017) Proteomic characterization of seminal plasma from 
alternative reproductive tactics of Chinook salmon (Oncorhynchus tshawytscha). J Proteomics 157:1-9

Gröning J, Hochkirch A (2008) Reproductive interference between animal species. Q Rev Biol 83(3):257-282

Groot C, Margolis L (eds) (1991) Pacific salmon life histories. UBC Press, Vancouver

Grosenick L, Clement TS, Fernald RD (2007) Fish can infer social rank by observation alone. Nature 445(7126):429

Gross MR (1984) Sunfish, Salmon, and the evolution of alternative reproductive strategies and tactics in fishes. In: Wootton R, Potts G (eds) Fish reproduction. Academic Press, London

Gross MR (1991) Salmon breeding behavior and life history evolution in changing environments. Ecology 72(4):1180-1186

Hamilton WD, Zuk M (1982) Heritable true fitness and bright birds: a role for parasites. Science 218(4570):384-387

Hanson AJ, Smith HD (1967) Mate selection in a population of sockeye salmon (Oncorhynchus nerka) of mixed agegroups. J Fish Res Board Can 24:1955-1977

Haugland T, Rudolfsen G, Figenschou L, Folstad I (2011) Is the adipose fin and the lower jaw (kype) related to social dominance in male Arctic charr Salvelinus alpinus? J Fish Biol 79:1076-1083

Hebets EA, Wesson J, Shamble PS (2008) Diet influences mate choice selectivity in adult female wolf spiders. Anim Behav 76:355-363

Hedrick AV, Dill LM (1993) Mate choice by female crickets is influenced by predation risk. Anim Behav 46(1):193-196

Hendry AP, Berg OK (1999) Secondary sexual characters, energy use, senescence, and the cost of reproduction in sockeye salmon. Can J Zool 77(11):1663-1675

Hendry AP, Quinn TP (1997) Variation in adult life history and morphology among Lake Washington sockeye salmon (Oncorhynchus nerka) populations in relation to habitat features and ancestral affinities. Can J Fish Aquat Sci 54:75-84

Hendry AP, Wenburg JK, Bentzen P, Volk EC, Quinn TP (2000) Rapid evolution of reproductive isolation in the wild: evidence from introduced salmon. Science 290:516-518

Hendry AP, Berg OK, Quinn TP (2001) Breeding location choice in salmon: causes (habitat, competition, body size, energy stores) and consequences (life span, energy stores). Oikos 93:407-418

Hesse S, Bakker TC, Baldauf SA, Thünken T (2016) Impact of social environment on inter-and intrasexual selection in a cichlid fish with mutual mate choice. Anim Behav 111:85-92

Hettyey A, Pearman PB (2003) Social environment and reproductive interference affect reproductive success in the frog Rana latastei. Behav Ecol 14(2):294-300

Hilderbrand GV, Schwartz CC, Robbins CT, Jacoby ME, Hanley TA, Arthur SM, Servheen C (1999) The importance of meat, particularly salmon, to body size, population productivity, and conservation of North American brown bears. Can J Zool 77:132-138

Honda H (1982) On the female sex pheromones and courtship behaviour in the salmonids, Oncorhynchus masou and Oncorhynchus rhodurus. Bull Jpn Soc Sci Fish 48:47-49
Hoover B, Nevitt G (2016) Modeling the importance of sample size in relation to error in MHC-based mate-choice studies on natural populations. Integr Comp Biol 56:925-933

Houde ALS, Fraser DJ, O'Reilly P, Hutchings JA (2010) Maternal and paternal effects on fitness correlates in outbred and inbred Atlantic salmon (Salmo salar). Can J Fish Aquat Sci 68:534-549

Houde ALS, Fraser DJ, O'Reilly P, Hutchings JA (2011) Relative risks of inbreeding and outbreeding depression in the wild in endangered salmon. Evol Appl 4:634-647

Howard RD, Martens RS, Innis SA, Drnevich JM, Hale J (1998) Mate choice and mate competition influence male body size in Japanese medaka. Anim Behav 55(5):1151-1163

Hoysak DJ, Liley NR (2001) Fertilization dynamics in sockeye salmon and a comparison of sperm from alternative male phenotypes. J Fish Biol 58:1286-1300

Hughes KA, Du L, Rodd FH, Reznick DN (1999) Familiarity leads to female mate preference for novel males in the guppy, Poecilia reticulata. Anim Behav 58(4):907-916

Hughes KA, Houde AE, Price AC, Rodd FH (2013) Mating advantage for rare males in wild guppy populations. Nature 503(7474):108-110

Huuskonen H, Haakana H, Kekäläinen J (2009) Offspring performance is linked to parental identity and male breeding ornamentation in whitefish. Biol J Linn Soc 98(3):532-539

Jacob A, Nusslé S, Britschgi A, Evanno G, Müller R, Wedekind C (2007) Male dominance linked to size and age, but not to 'good genes' in brown trout (Salmo trutta). BMC Evol Biol 7(1):207

Jacob A, Evanno G, von Siebenthal BA, Grossen C, Wedekind C (2010) Effects of different mating scenarios on embryo viability in brown trout. Mol Ecol 19:5296-5307

Janhunen M, Peuhkuri N, Primmer CR, Kolari I, Piironen J (2011) Does breeding ornamentation signal genetic quality in Arctic charr, Salvelinus alpinus? Evol Biol 38(1):68-78

Järvi T (1990) The effects of male dominance, secondary sexual characteristics and female mate choice on the mating success of male Atlantic salmon Salmo salar. Ethol 84:123-132

Jašarević E, Sieli PT, Twellman EE, Welsh TH, Schachtman TR, Roberts RM, Geary DC, Rosenfeld CS (2011) Disruption of adult expression of sexually selected traits by developmental exposure to bisphenol A. Proc Nat Acad Sci USA 108(28):11715-11720

Jašarević E, Geary DC, Rosenfeld CS (2012) Sexually selected traits: a fundamental framework for studies on behavioral epigenetics. ILAR J 53(3-4):253-269

Jirotkul K (1999) Operational sex ratio influences female preference and male-male competition in guppies. Anim Behav 58(2):287-294

Johnson JB, Basolo AL (2003) Predator exposure alters female mate choice in the green swordtail. Behav Ecol 14(5):619-625

Johnson SP, Carlson SM, Quinn TP (2006) Tooth size and skin thickness in mature sockeye salmon: evidence for habitat constraints and variable investment between the sexes. Ecol Freshw Fish 15(3):331-338

Katz J, Moyle PB, Quiñones RM, Israel J, Purdy S (2013) Impending extinction of salmon, steelhead, and trout (Salmonidae) in California. Environ Biol Fish 96:1169-1186 
Kazyak DC, Hilderbrand RH, King TL, Keller SR, Chhatre VE (2016) Hiding in plain sight: a case for cryptic metapopulations in Brook Trout (Salvelinus fontinalis). PLoS ONE 11:e0146295. https://doi.org/10.1371/journal.pone. 0146295

Keefer ML, Stansell RJ, Tackley SC, Nagy WT, Gibbons KM, Peery CA, Caudill CC (2012) Use of radiotelemetry and direct observations to evaluate sea lion predation on adult Pacific salmonids at Bonneville Dam. Trans Am Fish Soc 141:1236-1251

Keenleyside MH, Dupuis HM (1988) Courtship and spawning competition in pink salmon (Oncorhynchus gorbuscha). Can J Zool 66:262-265

Kekäläinen J, Huuskonen H, Tuomaala M, Kortet R (2010) Both male and female sexual ornaments reflect offspring performance in a fish. Evolution 64:3149-3157

Kekäläinen J, Pirhonen J, Taskinen J (2014) Do highly ornamented and less parasitized males have high quality sperm? An experimental test for parasite-induced reproductive trade-offs in European minnow (Phoxinus phoxinus). Ecol Evol 4(22):4237-4246

Kekäläinen J, Soler C, Veentaus S, Huuskonen H (2015) Male investments in high quality sperm improve fertilization success, but may have negative impact on offspring fitness in whitefish. PLoS ONE 10(9):e0137005

Keller MJ, Gerhardt HC (2001) Polyploidy alters advertisement call structure in gray treefrogs. Proc $R$ Soc $B$ 268(1465):341-345

Kendall NW, Quinn TP (2013) Size-selective fishing affects sex ratios and the opportunity for sexual selection in Alaskan sockeye salmon Oncorhynchus nerka. Oikos 122:411-420

Kennedy CEJ, Endler JA, Poynton SL, McMinn H (1987) Parasite load predicts mate choice in guppies. Behav Ecol Sociobiol 21(5):291-295

Kincaid HL (1976) Inbreeding in rainbow trout (Salmo gairdneri). J Fish Res Board Can 33:2420-2426

Kitanishi S, Yamamoto T (2015) Comparison of genetic structure between juvenile and adult masu salmon indicates relatively low reproductive success of dispersers. Environ Biol Fish 98:405-411

Kortet R, Vainikka A, Janhunen M, Piironen J, Hyvärinen P (2014) Behavioral variation shows heritability in juvenile brown trout Salmo trutta. Behav Ecol Sociobiol 68(6):927

Kotrschal A, Taborsky B (2010) Environmental change enhances cognitive abilities in fish. PLoS Biol 8:e1000351

Labonne J, Augery M, Parade M, Brinkert S, Prevost E, Héland M, Beall E (2009) Female preference for male body size in brown trout, Salmo trutta: is big still fashionable? Anim Behav 77:129-137

Landry C, Garant D, Duchesne P, Bernatchez L (2001) Good genes as heterozygosity: the major histocompatibility complex and mate choice in Atlantic salmon (Salmo salar). Proc R Soc B 268:1279-1285

Larson WA, Lisi PJ, Seeb JE, Seeb LW, Schindler DE (2016) Major histocompatibility complex diversity is positively associated with stream water temperatures in proximate populations of sockeye salmon. J Evol Biol 29:1846-1859

Le Comber SC, Smith C (2004) Polyploidy in fishes: patterns and processes. Biol J Linn Soc 82(4):431-442

Le Luyer J, Laporte M, Beacham TD, Kaukinen KH, Withler RE, Leong JS, Rondeau EB, Koop BF, Bernatchez L
(2017) Parallel epigenetic modifications induced by hatchery rearing in a Pacific salmon. Proc Nat Acad Sci USA 114(49):12964-12969

Leggatt RA, Iwama GK (2003) Occurrence of polyploidy in the fishes. Rev Fish Biol Fish 13(3):237-246

Lehnert SJ, Love OP, Pitcher TE, Higgs DM, Heath DD (2014) Multigenerational outbreeding effects in Chinook salmon (Oncorhynchus tshawytscha). Genetica 142(4):281-293

Lehnert SJ, Heath DD, Devlin RH, Pitcher TE (2016a) Postspawning sexual selection in red and white Chinook salmon (Oncorhynchus tshawytscha). Behav Ecol 28:1-10

Lehnert SJ, Pitcher TE, Devlin RH, Heath DD (2016b) Red and white Chinook salmon: genetic divergence and mate choice. Mol Ecol 25:1259-1274

Lehnert SJ, Butts IAE, Flannery EW, Peters KM, Heath DD, Pitcher TE (2017) Effects of ovarian fluid and genetic differences on sperm performance and fertilization success of alternative reproductive tactics in Chinook salmon. J Evol Biol 30(6):1236-1245

Lenington S (1991) The $t$-complex: a story of genes, behavior, and populations. Adv Stud Behav 20:51-86

Lewis JA, Pitcher TE (2017) The effects of rival seminal plasma on sperm velocity in the alternative reproductive tactics of Chinook salmon. Theriogenology 92:24-29

Liley NR, Tamkee P, Tsai R, Hoysak DJ (2002) Fertilization dynamics in rainbow trout (Oncorhynchus mykiss): effect of male age, social experience, and sperm concentration and motility on in vitro fertilization. Can J Fish Aquat Sci 59:144-152

Liljedal S, Folstad I, Skarstein F (1999) Secondary sex traits, parasites, immunity and ejaculate quality in the Arctic charr. Proc R Soc B 266:1893-1898

Liljedal S, Rudolfsen G, Folstad I (2008) Factors predicting male fertilization success in an external fertilizer. Behav Ecol 62:1805

Lindholm AK, Dyer KA, Firman RC, Fishman L, Forstmeier W, Holman L, Johannesson H, Knief U, Kokko H, Larracuente AM, Manser A, Montchamp-Moreau C, Petrosyan VG, Pomiankowski A, Presgraves DC, Safronova LD, Sutter A, Unckless RL, Verspoor RL, Wedell N, Wilkinson GS, Price TAR (2016) The ecology and evolutionary dynamics of meiotic drive. Trends Ecol Evol 31(4):315-326

Liu S, Luo J, Chai J, Ren L, Zhou Y, Huang F, Liu X, Chen Y, Chun Z, Tao M, Lu B, Zhou W, Lin G, Mai C, Yuan S, Wang J, Li T, Qin Q, Feng H, Kaikun L, Xio J, Zhong H, Zhao R, Duan W, Song Z, Wang Y, Wang J, Zhong L, Wang L, Ding Z, Du Z, Lu X, Gao Y, Murphy RW, Liu Y, Meyer A, Zhang Y-P (2016) Genomic incompatibilities in the diploid and tetraploid offspring of the goldfish $\mathrm{x}$ common carp cross. Proc Nat Acad Sci USA 113(5):1327-1332

Locatello L, Poli F, Rasotto MB (2013) Tactic-specific differences in seminal fluid influence sperm performance. Proc R Soc Lond B 280:20122891

Lopez S (1999) Parasitized female guppies do not prefer showy males. Anim Behav 57:1129-1134

Lucon-Xiccato T, Bisazza A (2017) Individual differences in cognition among teleost fishes. Behav Process 141(2):184-195

Lumley AJ, Diamond SE, Einum S, Yeates SE, Peruffo D, Emerson BC, Gage MJ (2016) Post-copulatory opportunities for sperm competition and cryptic female choice 
provide no offspring fitness benefits in externally fertilizing salmon. R Soc Open Sci 3:150709

Mable BK, Alexandrou MA, Taylor MI (2011) Genome duplication in amphibians and fish: an extended synthesis. J Zool 284(3):151-182

Maekawa K, Shigeru N, Yamamoto S (1994) Spawning behaviour and size-assortative mating of Japanese charr in an artificial lake-inlet stream system. Environ Biol Fish 39(2):109-117

Magurran AE, Seghers BH (1990) Risk sensitive courtship in the guppy (Poecilia reticulata). Behaviour 112(3):194-201

Makiguchi Y, Ichimura M, Kitayama T, Kawabata Y, Kitagawa T, Kojima T, Pitcher TE (2016a) Sperm allocation in relation to female size in a semelparous salmonid. R Soc Open Sci 3(12): 160497

Makiguchi Y, Torao M, Kojima T, Pitcher TE (2016b) Reproductive investment patterns and comparison of sperm quality in the presence and absence of ovarian fluid in alternative reproductive tactics of masu salmon, Oncorhynchus masou. Theriogenology 86(9):2189-2193

Manser A, Lindholm AK, Simmons LW, Firman RC (2017) Sperm competition suppresses gene drive among experimentally evolving populations of house mice. Mol Ecol 20:5784-5792

Marshall DJ (2015) Environmentally induced (co) variance in sperm and offspring phenotypes as a source of epigenetic effects. J Exp Biol 218(1):107-113

Marshall DL, Ellstrand NC (1988) Effective mate choice in wild radish: evidence for selective seed abortion and its mechanism. Am Nat 131(5):739-756

Martin-Wintle MS, Wintle NJP, Díez-León M, Swaisgood RR, Asa CS (2018) Improving the sustainability of ex situ populations with mate choice. Zoo Biol. https://doi.org/10. 1002/zoo. 21450

Mashoodh R, Franks B, Curley JP, Champagne FA (2012) Paternal social enrichment effects on maternal behavior and offspring growth. Proc Nat Acad Sci 109(Supplement 2):17232-17238

Mathisen OA (1962) The effect of altered sex ratios on the spawning of red salmon. In: Koo TSY (ed) Studies of Alaska red salmon. University of Washington Press, Seattle

Mazzi D (2004) Parasites make male pipefish careless. J Evol Biol 17(3):519-527

Milinski M, Bakker TC (1990) Female sticklebacks use male coloration in mate choice and hence avoid parasitized males. Nature 344(6264):330

Miyatake T, Shimizu T (1999) Genetic correlations between life-history and behavioral traits can cause reproductive isolation. Evolution 53(1):201-208

Mjølnerød IB, Fleming IA, Refseth UH, Hindar K (1998) Mate and sperm competition during multiple-male spawnings of Atlantic salmon. Can J Zool 76:70-75

Morbey YE (2000) Protandry in Pacific salmon. Can J Fish Aquat Sci 57:1252-1257

Morbey YE (2002) The mate-guarding behaviour of male kokanee Oncorhynchus nerka. Behaviour 139:507-528

Moreira AL, Taylor EB (2015) The origin and genetic divergence of "black" kokanee, a novel reproductive ecotype of
Oncorhynchus nerka. Can J Fish Aquat Sci 72(10):1584-1595

Näslund J, Larsen MH, Thomassen ST, Aarestrup K, Johnsson JI (2017) Environment-dependent plasticity and ontogenetic changes in the brain of hatchery-reared Atlantic salmon. J Zool 301(1):75-82

Neff BD, Garner SR, Heath JW, Heath DD (2008) The MHC and non-random mating in a captive population of Chinook salmon. Heredity 101:175-185

Nordeide JT (2006) Is there more in 'gamete quality' than quality of the gametes? A review of effects of female mate choice and genetic compatibility on offspring quality. Aquac Res 38(1):1-16

Ödeen A, Moray CM (2008) Drosophila melanogaster virgins are more likely to mate with strangers than familiar flies. Naturwissenschaften 95(3):253-256

Okuyama T, Yokoi S, Abe H, Isoe Y, Suehiro Y, Imada H, Tanaka M, Kawasaki T, Yuba S, Taniguchi Y, Kamei Y (2014) A neural mechanism underlying mating preferences for familiar individuals in medaka fish. Science 343(6166):91-94

Oliveira RF, Hirschenhauser K, Carneiro LA, Canario AV (2002) Social modulation of androgen levels in male teleost fish. Comp Biochem Physiol B-Biochem Mol 132(1):203-215

Olsén H, Grahn M, Lohm J, Langefors Å (1998) MHC and kin discrimination in juvenile Arctic charr, Salvelinus alpinus (L.). Anim Behav 56:319-327

Pélabon C, Borg ̊̊A, Bjelvenmark J, Barber I, Forsgren E, Amundsen T (2005) Do microsporidian parasites affect courtship in two-spotted gobies? Mar Biol 148:189-196

Perret M (1992) Environmental and social determinants of sexual function in the male lesser mouse lemur (Microcebus murinus). Folia Primatol 59(1):1-25

Perrier C, Normandeau É, Dionne M, Richar A, Bernatchez L (2014) Alternative reproductive tactics increase effective population size and decrease inbreeding in wild Atlantic salmon. Evol Appl 7:1094-1106

Peterson DA, Hilborn R, Hauser L (2014) Local adaptation limits lifetime reproductive success of dispersers in a wild salmon metapopulation. Nat Commun 5:3696

Petersson E, Järvi T, Olsén H, Mayer I, Hedenskog M (1999) Male-male competition and female choice in brown trout. Anim Behav 57(4):777-783

Pitcher TE, Neff BD (2007) Genetic quality and offspring performance in Chinook salmon: implications for supportive breeding. Conserv Genet 8:607-616

Pitcher TE, Doucet SM, Beausoleil J-MJ, Hanley D (2009) Secondary sexual characters and sperm traits in coho salmon Oncorhynchus kisutch. J Fish Biol 74(7):1450-1461

Price TA, Wedell N (2008) Selfish genetic elements and sexual selection: their impact on male fertility. Genetica 134:99

Promerová M, Alavioon G, Tusso S, Burri R, Immler S (2017) No evidence for MHC class II-based non-random mating at the gametic haplotype in Atlantic salmon. Heredity 118(6):563-567

Pusey A, Wolf M (1996) Inbreeding avoidance in animals. Trends Ecol Evol 11(5):201-206

Quinn TP, Buck GB (2001) Size-and sex-selective mortality of adult sockeye salmon: bears, gulls, and fish out of water. Trans Am Fish Soc 130:995-1005 
Quinn TP, Busack CA (1985) Chemosensory recognition of siblings in juvenile coho salmon (Oncorhynchus kisutch). Anim Behav 33:51-56

Quinn TP, Foote CJ (1994) The effects of body size and sexual dimorphism on the reproductive behaviour of sockeye salmon, Oncorhynchus nerka. Anim Behav 48:751-761

Quinn TP, Kinnison MT (1999) Size-selective and sex-selective predation by brown bears on sockeye salmon. Oecologia 121:272-282

Quinn TP, Adkison MD, Ward MB (1996) Behavioral tactics of male sockeye salmon (Oncorhynchus nerka) under varying operational sex ratios. Ethology 102:304-322

Quinn TP, Volk EC, Hendry AP (1999) Natural otolith microstructure patterns reveal precise homing to natal incubation sites by sockeye salmon (Oncorhynchus nerka). Can J Zool 77(5):766-775

Quinn TP, Hendry AP, Buck GB (2001) Balancing natural and sexual selection in sockeye salmon: interactions between body size, reproductive opportunity and vulnerability to predation by bears. Evol Ecol Res 3:917-937

Quinn TP, Gende SM, Ruggerone GT, Rogers DE (2003) Density-dependent predation by brown bears (Ursus arctos) on sockeye salmon (Oncorhynchus nerka). Can J Fish Aquat Sci 60:553-562

Quinn TP, Stewart IJ, Boatright CP (2006) Experimental evidence of homing to site of incubation by mature sockeye salmon, Oncorhynchus nerka. Anim Behav 72(4):941-949

Rajakaruna RS, Brown JA, Kaukinen KH, Miller KM (2006) Major histocompatibility complex and kin discrimination in Atlantic salmon and brook trout. Mol Ecol 15:4569-4575

Ramstad KM, Woody CA, Allendorf FW (2010) Recent local adaptation of sockeye salmon to glacial spawning habitats. Evol Ecol 24:391-411

Randall JA, Hekkala ER, Cooper LD, Barfield J (2002) Familiarity and flexible mating strategies of a solitary rodent, Dipodomys ingens. Anim Behav 64(1):11-21

Reed TE, Prodöhl P, Hynes R, Cross T, Ferguson A, McGinnity P (2015) Quantifying heritable variation in fitness-related traits of wild, farmed and hybrid Atlantic salmon families in a wild river environment. Heredity 115:173-184

Reimchen TE, Temple NF (2004) Hydrodynamic and phylogenetic aspects of the adipose fin in fishes. Can J Zool 82:910-916

Reusch TBH, Ehlers A, Hämmerli A, Worm B (2005) Ecosystem recovery after climatic extremes enhanced by genotypic diversity. PNAS 102(8):2826-2831

Ritchie H, Marshall DJ (2013) Fertilisation is not a new beginning: sperm environment affects offspring developmental success. J Exp Biol 216(16):3104-3109

Rodewald P, Hyvärinen P, Hirvonen H (2011) Wild origin and enriched environment promote foraging rate and learning to forage on natural prey of captive reared Atlantic salmon parr. Ecol Freshw Fish 20(4):569-579

Rosengrave P, Gemmell NJ, Metcalf V, McBride K, Montgomerie R (2008) A mechanism for cryptic female choice in Chinook salmon. Behav Ecol 19:1179-1185

Rosengrave P, Taylor H, Montgomerie R, Metcalf V, McBride K, Gemmell NJ (2009) Chemical composition of seminal and ovarian fluids of Chinook salmon (Oncorhynchus tshawytscha) and their effects on sperm motility traits.
Comp Biochem Physiol A Mol Integr Physiol 152(1):123-129

Rosengrave P, Montgomerie R, Gemmell N (2016) Cryptic female choice enhances fertilization success and embryo survival in Chinook salmon. Proc R Soc B 283:20160001

Rouger Y, Liley NR (1993) Effect of social environment on plasma hormones and availability of milt in spawning male rainbow trout (Oncorhynchus mykiss Walbaum). Can J Zool 71:280-285

Rudolfsen G, Figenschou L, Folstad Tveiten H, Figenschou M (2006) Rapid adjustments of sperm characteristics in relation to social status. Proc R Soc B 273:325-332

Rudolfsen G, Müller R, Urbach D, Wedekind C (2008) Predicting the mating system from phenotypic correlations between life-history and sperm quality traits in the Alpine whitefish Coregonus zugensis. Behav Ecol Sociol 62(4):561-567

Rudolfsen G, Serrano JV, Folstad I (2015) Own, but not foreign seminal fluid inhibits activation in a vertebrate with external fertilization. Front Ecol Evol 3:92

Ryan MJ (1980) Female mate choice in a neotropical frog. Science 209(4455):523-525

Ryman N (1981) Conservation of genetic resources: experiences from the brown trout ("Salmo trutta"). Ecol Bull 34:61-74

Salvanes AGV, Moberg O, Ebbesson LO, Nilsen TO, Jensen KH, Braithwaite VA (2013) Environmental enrichment promotes neural plasticity and cognitive ability in fish. Proc R Soc B 280:20131331

Sargent RC, Gross MR, Van Den Berghe EP (1986) Male mate choice in fishes. Anim Behav 34:545-550

Satou M, Takeuchi HA, Takei K, Hasegawa T, Matsushima T, Okumoto N (1994) Characterization of vibrational and visual signals which elicit spawning behavior in the male hime salmon (landlocked red salmon, Oncorhynchus nerka). J Comp Physiol A 174:527-537

Scherer U, Kuhnhard M, Schuett W (2017) Different or alike? Female rainbow kribs choose males of similar consistency and dissimilar level of boldness. Anim Behav 128:117-124

Schlupp I, Ryan MJ (1997) Male sailfin mollies (Poecilia latipinna) copy the mate choice of other males. Behav Ecol 8(1):104-107

Schultzhaus JN, Nixon JJ, Duran JA, Carney GE (2017) Diet alters Drosophila melanogaster mate preference and attractiveness. Anim Behav 123:317-327

Seamons TR, Bentzen P, Quinn TP (2004) The effects of adult length and arrival date on individual reproductive success in wild steelhead trout (Oncorhynchus mykiss). Can J Fish Aquat Sci 61(2):193-204

Serbezov D, Bernatchez L, Olsen EM, Vøllestad LA (2010) Mating patterns and determinants of individual reproductive success in brown trout (Salmo trutta) revealed by parentage analysis of an entire stream living population. Mol Ecol 19:3193-3205

Shohet AJ, Watt PJ (2009) Female guppies Poecilia reticulata prefer males that can learn fast. J Fish Biol 75(6):1323-1330

Sih A, Ferrari MC, Harris DJ (2011) Evolution and behavioural responses to human-induced rapid environmental change. Evol Appl 4(2):367-387 
Skaala Ø, Nævdal G (1989) Genetic differentiation between freshwater resident and anadromous brown trout, Salmo trutta, within watercourses. J Fish Biol 34(4):597-605

Skarstein F, Folstad I, Liljedal S, Grahn M (2005) MHC and fertilization success in the Arctic charr (Salvelinus alpinus). Behav Ecol Sociobiol 57:374-380

Skau PA, Folstad I (2005) Does immunity regulate ejaculate quality and fertility in humans? Behav Ecol 16(2):410-416

Skinner MK, Savenkova MI, Zhang B, Gore AC, Crews D (2014) Gene bionetworks involved in the epigenetic transgenerational inheritance of altered mate preference: environmental epigenetics and evolutionary biology. BMC Genomics 15(1):0377

Smith BR, Blumstein DT (2008) Fitness consequences of personality: a meta-analysis. Behav Ecol 19(2):448-455

Sneddon LU (2003) The bold and the shy: individual differences in rainbow trout. J Fish Biol 62:971-975

Soltis PS, Soltis DE (2000) The role of genetic and genomic attributes in the success of polyploids. Proc Natl Acad Sci USA 97(13):7051-7057

Sørum V, Figenschou L, Rudolfsen G, Folstad I (2011) Spawning behaviour of Arctic charr (Salvelinus alpinus): risk of sperm competition and timing of milt release for sneaker and dominant males. Behaviour 148:1157-1172

Steen RP, Quinn TP (1999) Egg burial depth by sockeye salmon (Oncorhynchus nerka): implications for survival of embryos and natural selection on female body size. Can J Zool 77(5):836-841

Sveinsson T, Hara TJ (1995) Mature males of Arctic charr, Salvelinus alpinus, release F-type prostaglandins to attract conspecific mature females and stimulate their spawning behaviour. Environ Biol Fish 42:253-266. https://doi.org/ 10.1007/BF00004919

Taborsky B, Oliveira RF (2012) Social competence: an evolutionary approach. Trends Ecol Evol 27(12):679-688

Taborsky B, Tschirren L, Meunier C, Aubin-Horth N (2013) Stable reprogramming of brain transcription profiles by the early social environment in a cooperatively breeding fish. Proc R Soc B 280(1753):20122605

Tautz AF, Groot C (1975) Spawning behavior of chum salmon (Oncorhynchus keta) and rainbow trout (Salmo gairdneri). J Fish Res Board Can 32:633-642

Tentelier C, Larranaga N, Lepais O, Manicki A, Rives J, Lange F (2016) Space use and its effects on reproductive success of anadromous Atlantic salmon. Can J Fish Aquat Sci 73:1461-1471

Thériault V, Bernatchez L, Dodson JJ (2007) Mating system and individual reproductive success of sympatric anadromous and resident brook charr, Salvelinus fontinalis, under natural conditions. Behav Ecol Sociobiol 62(1):51-65

Thomaz DMPF, Beall E, Burke T (1997) Alternative reproductive tactics in Atlantic salmon: factors affecting mature parr success. Proc R Soc B 264:219-226

Thorn MW, Morbey YE (2016) Evidence for the secondary sexual development of the anal fin in female kokanee salmon Oncorhynchus nerka. J Fish Biol 88:448-458

Tokarz RR (1992) Male mating preference for unfamiliar females in the lizard, Anolis sagrei. Anim Behav 44(5):843-849
Tryjanowski P, Sparks TH, Ptaszyk J, Kosicki J (2010) Do white storks Ciconia ciconia always profit from an early return to their breeding grounds? Bird Study 51(3):222-227

Turner SM, Chaves-Campos J, DeWoody JA (2009) Parental relatedness and major histocompatibility effects on early embryo survivorship in Atlantic salmon. Genetica 137:99-109

Tuttle MD, Taft LK, Ryan MJ (1982) Evasive behaviour of a frog in response to bat predation. Anim Behav 30(2):393-397

Vakirtzis A (2011) Mate choice copying and nonindependent mate choice: a critical review. Ann Zool Fenn 48(2):91-107

Valone TJ, Templeton JJ (2002) Public information for the assessment of quality: a widespread social phenomenon. Philos Trans R Soc Lond B Biol Sci 357(1427):1549-1557

Valtonen TM, Kangassalo K, Pölkki M, Rantala MJ (2012) Transgenerational effects of parental larval diet on offspring development time, adult body size and pathogen resistance in Drosophila melanogaster. PLoS ONE 7(2):e31611

Van den Berghe EP, Gross MR (1984) Female size and nest depth in coho salmon (Oncorhynchus kisutch). Can J Fish Aquat Sci 41:204-206

Van den Berghe EP, Gross MR (1989) Natural selection resulting from female breeding competition in a Pacific salmon (coho: Oncorhynchus kisutch). Evolution 48:125-140

Van der Haegen GE, Blankenship HL, Hoffmann A, Thompson DA (2005) The effects of adipose fin clipping and coded wire tagging on the survival and growth of spring Chinook salmon. N Am J Fish Manag 25(3):1161-1170

Verspoor E (1997) Genetic diversity among Atlantic salmon (Salmo salar L.) populations. ICES J Mar Sci 54:965-973

Vilhunen S, Hirvonen H, Laakkonen MV (2005) Less is more: social learning of predator recognition requires a low demonstrator to observer ratio in Arctic charr (Salvelinus alpinus). Behav Ecol Sociobiol 57(3):275-282

Vilhunen S, Tiira K, Laurila A, Hirvonen H (2008) The bold and the variable: fish with high heterozygosity act recklessly in the vicinity of predators. Ethology 114(1):7-15

Vladić T, Forsberg LA, Järvi T (2010) Sperm competition between alternative reproductive tactics of the Atlantic salmon in vitro. Aquaculture 302(3-4):265-269

Wang S, Hard JJ, Utter F (2002) Salmonid inbreeding: a review. Rev Fish Biol Fish 11:301-319

Wasser SK, Lundin JI, Ayres K, Seely E, Giles D, Balcomb K, Hempelmann J, Parsons K, Booth R (2017) Population growth is limited by nutritional impacts on pregnancy success in endangered southern resident killer whales (Orcinus orca). PLoS ONE 12(6):e0179824. https://doi. org/10.1371/journal.pone.0179824

Watanabe M, Takamura S, Maekawa K (2008) Effects of timing of nest entry and body size on the fertilization success of alternative male reproductive phenotypes of masu salmon (Oncorhynchus masou). Can J Zool 86:1121-1130

Weaver IC, Cervoni N, Champagne FA, D'Alessio AC, Sharma S, Seckl JR, Dymov S, Szyf M, Meaney MJ (2004) Epigenetic programming by maternal behavior. Nat Neurosci 7(8):847-854 
Wedekind C, Müller R, Spicher H (2001) Potential genetic benefits of mate selection in whitefish. J Evol Biol 14:980-986

Wedekind C, Walker M, Portmann J, Cenni B, Müller R, Binz T (2004) MHC-linked susceptibility to a bacterial infection, but no MHC-linked cryptic female choice in whitefish. Evol Biol 17:11-18

Wedekind C, Jacob A, Evanno G, Nusslé S, Müller R (2008) Viability of brown trout embryos positively linked to melanin-based but negatively to carotenoid-based colours of their fathers. Proc R Soc B 275:1737-1744

Wedell N (2013) The dynamic relationship between polyandry and selfish genetic elements. Proc R Soc B 368:20120049

Weir LK, Hutchings JA, Heath DD (2012) Influence of density and major histocompatibility genotype on sexual selection in a salmonid alternative mating strategy. Can J Fish Aquat Sci 69:670-680

Werren JH (2011) Selfish genetic elements, genetic conflict, and evolutionary innovation. Proc Nat Acad USA 108(2):10863-10870

Westley PA, Carlson SM, Quinn TP (2008) Among-population variation in adipose fin size parallels the expression of other secondary sexual characteristics in sockeye salmon (Oncorhynchus nerka). Environ Biol Fish 81(4):439-446

Whitcomb AC, Banks MA, O'Malley KG (2014) Influence of immune-relevant genes on mate choice and reproductive success in wild-spawning hatchery reared and wild-born coho salmon (Oncorhynchus kisutch). Can J Fish Aquat Sci 71(7):1000-1009

White DJ, Galef BG Jr (1999) Mate choice copying and conspecific cueing in Japanese quail, Coturnix coturnix japonica. Anim Behav 57(2):465-473

Wilkinson GS, Presgraves DC, Crymes L (1998) Male eye span in stalk-eyed flies indicates genetic quality by meiotic drive suppression. Nature 391:276-279
Wilson MF, Burley N (1983) Mate choice in plants. Princeton University Press, Princeton

Wilson AD, Stevens ED (2005) Consistency in context-specific measures of shyness and boldness in rainbow trout, $\mathrm{On}$ corhynchus mykiss. Ethology 111:849-862

Witte K (2006) Learning and mate choice. In: Brown C, Lalande K, Krause J (eds) Fish Cognition and Behavior. Blackwell, London, pp 70-95

Wong BBM, Candolin U (2005) How is female mate choice affected by male competition. Biol Rev 80:559-571

Yamamnoto D, Koganezawa M (2013) Genes and circuits of courtship behaviour in Drosophila males. Nat Rev Neurosci 14(10):681-692

Yambe H, Yamazaki F (2001) Species-specific releaser effect of urine from ovulated female masu salmon and rainbow trout. J Fish Biol 59:1455-1464

Yeates SE, Einum S, Fleming IA, Megens HJ, Stet RJ, Hindar K, Holt WV, Van Look KJW, Gage MJ (2009) Atlantic salmon eggs favour sperm in competition that have similar major histocompatibility alleles. Proc R Soc B 276:559-566

Yeates SE, Diamond SE, Einum S, Emerson BC, Holt WV, Gage MJ (2013) Cryptic choice of conspecific sperm controlled by the impact of ovarian fluid on sperm swimming behavior. Evolution 67(12):3523-3536

Young B, Conti DV, Dean MD (2013) Sneaker "jack" males outcompete dominant "hooknose" males (Oncorhynchus tshawytscha). Ecol Evol 3(15):4987-4997

Zahavi A (1975) Mate selection-a selection for a handicap. J Theor Biol 53(1):205-214

Zhou R, Cheng H, Tiersch TR (2002) Differential genome duplication and fish diversity. Rev Fish Biol Fish 11(4):331-337

Zuk M, Pompa SL, Johnsen TS (1995) Male courtship displays, ornaments and female mate choice in captive red jungle fowl. Behaviour 132(11/12):821-836 